Purdue University

Purdue e-Pubs

Purdue CIBER Working Papers

Krannert Graduate School of Management

$1-1-1999$

\title{
Stock Index Futures Trading and Volatility in International Equity Markets
}

Huseyin Gulen

Purdue University

Stewart Mayhew

Purdue University

Follow this and additional works at: http://docs.lib.purdue.edu/ciberwp

Gulen, Huseyin and Mayhew, Stewart, "Stock Index Futures Trading and Volatility in International Equity Markets" (1999). Purdue CIBER Working Papers. Paper 144.

http://docs.lib.purdue.edu/ciberwp/144

This document has been made available through Purdue e-Pubs, a service of the Purdue University Libraries. Please contact epubs@purdue.edu for additional information. 
Center for International

Business Education and Research

\section{Stock Index Futures Trading and Volatility in International Equity Markets}

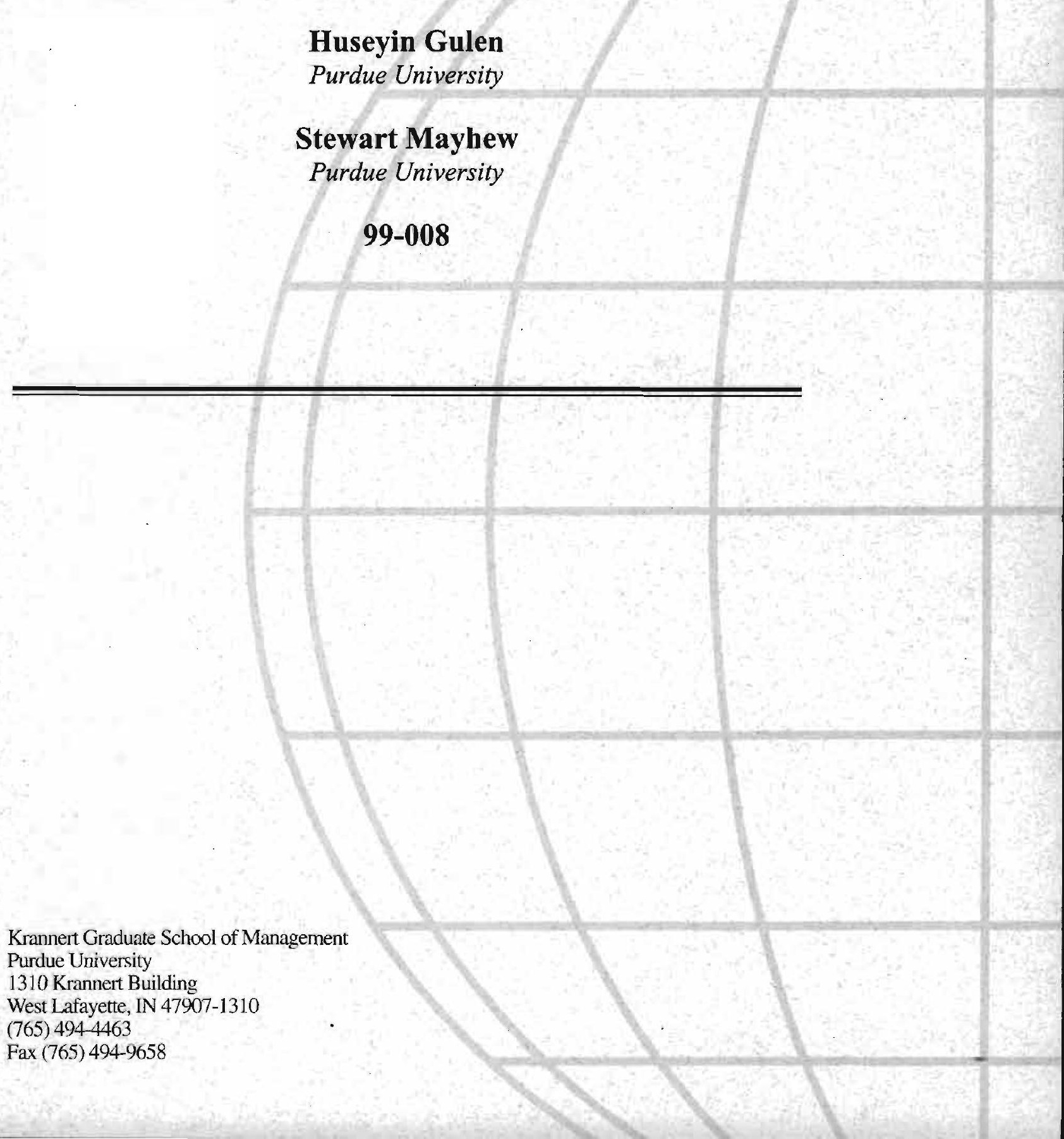




\title{
Stock Index Futures Trading and Volatility in International Equity Markets ${ }^{1}$
}

\author{
Huseyin Gulen \\ Stewart Mayhew \\ Krannert School of Management \\ 1310 Krannert Building \\ Purdue University \\ West Lafayette, IN 47907-1310
}

March 16, 1998

Revised: September 29, 1999

\footnotetext{
${ }^{1}$ We would like to thank Mike Cooper, Jin-Chuan Duan, Robert Engle, Andrew Karolyi, Ken Kroner, Alexandra MacKay, John McConnell, Ken Ratliff, and Joshua Rosenberg. Earlier versions of this paper were presented at Virginia Tech, the Spring 1998 Chicago Board of Trade Research Symposium, the Istanbul Stock Exchange, Purdue University, and the 1999 meetings of the American Finance Association. Mayhew would like to thank the Center for International Business Education and Research (CIBER) for funding this project.
} 


\title{
Stock Index Futures Trading and Volatility in International Equity Markets
}

\begin{abstract}
We examine stock market volatility before and after the introduction of equity index futures trading in twenty-five countries using various models that account for asynchronous data, conditional heteroskedasticity, asymmetric volatility responses, and the joint dynamics of each country's index with the world market portfolio. We find that futures trading is related to an increase in conditional volatility in the United States and Japan, but in nearly every other country, we find either no significant effect, or volatility-dampening effect. This result appears to be robust to model specification, and is corroborated by further analysis of the relationship between volatility, trading volume and open interest in stock index futures. We also document an increase in conditional covariance between country-specific and world returns at the time of futures listing.
\end{abstract}


The world's first stock index futures contract was the Value Line contract, introduced by the Kansas City Board of Trade on February 24, 1982. Today, stock index futures and options trade in markets all over the world, with new contracts launched nearly every year. Table 1 reports launch dates for thirty nations that introduced stock index futures between 1982 and January, 1998. In addition, plans are underway for exchange-listed index futures in many other nations, including Argentina, Colombia, Costa Rica, Mexico and Peru, India, Indonesia, Czech Republic, Slovakia, Greece, and Turkey.

As exchange-traded stock index futures and other derivatives become more pervasive in the world's financial markets, it is increasingly important to understand the effect of derivatives trading on the underlying markets, particularly in emerging economies. Previous literature on the effects of stock index futures trading has focused primarily on developed markets. Moreover, the existing research has come to conflicting conclusions regarding the effect of futures trading on volatility. Some authors have found that volatility appears to increase with the introduction of futures, and some find no significant effect, and some find that volatility decreases. ${ }^{1}$

This paper examines the time series properties of stock indexes in twenty-five countries, in order to investigate the impact of stock index futures listing and subsequent trading activity on the volatility structure of the underlying cash market. Not only do we test for structural changes at the time of futures listing by comparing properties of the returns series before and after listing, but we also test whether volatility in the post-listing period is related to futures market volume and open interest. The results of both tests show that futures trading is associated with increased volatility in the United States and Japan, but in virtually every one of the other twenty-three countries, this is not the case.

Various theories have been advanced elsewhere for how the introduction of futures might impact

\footnotetext{
${ }^{1}$ For a detailed summary of this literature, see surveys by Hodges (1992), Damodaran and Subrahmanyam (1992), Sutcliffe (1997) and Mayhew (1999).
} 
the volatility of the underlying market. As pointed out by Hodges (1992), Mayhew (1999) and others, many of these theories predict that volatility can increase or decrease with the introduction of futures, depending on the underlying assumptions, or depending on the parameter values used in the models. One interpretation of our result is that futures influence the underlying market through multiple, offsetting channels, with the relative importance of the effects depending on the extent of the development of the market. In particular, it appears that futures markets may play an important role in stabilizing less-developed markets.

Our paper contributes to the existing literature in several ways. To the best of our knowledge, it examines a much broader cross section of international futures introductions than any prior study, and is the first to examine the impact of futures markets in a cross-section of emerging nations. Included in our sample are the markets examined by previous authors, such as Lee and Ohk (1992), and Antoniou, Holmes and Priestly (1998), but with considerably larger sample periods. ${ }^{2}$ We examine the properties of excess returns over the world market index. This enables us to avoid attributing worldwide price movements, such as the crash of October 1987, to the listing of futures in the local market. In addition, this is the first paper, to our knowledge, that examines the relationship of volatility to futures market volume and open interest for a large cross-section of markets.

The basic approach of our anaysis is to test the the impact of futures introduction on volatility using a modification of the Generalized Auto-Regressive Conditional Heteroskedasticity model suggested by Glosten, Jagannathan and Rundle (1993) (GJR-GARCH). To test for the impact of futures trading we incorporate a multiplicative dummy variable in the conditional variance equation. We check the robustness of our results using various alternative specifications. Next, using a technique similar to then employed by Bessembinder and Seguin (1992), we decompose the trading volume and open interest time series into permanent and temporary components, and test how these components affect volatility by inserting them into the conditional volatility equation. Fi-

\footnotetext{
${ }^{2}$ Engle and Mezrich (1995) suggest using at least eight years of daily data for proper GARCH estimation.
} 
nally, we analyze the joint dynamics of each country with the world market portfolio using the bivariate GARCH specification advanced by Engle and Kroner (1995), commonly known as the BEKK model. ${ }^{3}$ This richer framework allows us to more carefully control for movements in global markets. It also allows us to test whether the conditional covariance between a country's return and the world market return changed with futures listing.

The remainder of this paper proceeds as follows. Section I describes the data we used in our analysis. It also reports the results of simple variance ratio tests of whether the variance of raw returns is higher or lower after the introduction of futures. The results of these simple tests suggest that volatility declines more often than it increases in response to futures listing. In section II, we describe the univariate GJR-GARCH framework we use to analyze the data, we verify that conditional heteroskedasticity is present in the returns in all twenty-five countries, and we test whether volatility is higher or lower after the introduction of futures trading. We also discuss the robustness of the results to model specification. In section III we examine whether conditional volatility is related to the temporary and permanent components of open interest and trading volume. In section IV we present our analysis of the joint dynamics of country-specific and world returns using the BEKK bivariate model.

\section{Data}

Daily stock market index data were obtained from Datastream ${ }^{4}$ for twenty-five of the thirty nations listed in Table 1. Russia, Venezuela, and Poland, which listed futures after July 1996, were excluded because in our judgment, there was insufficient data in the post-event period to draw any meaningful conclusions. Brazil and New Zealand were excluded due to lack of data.

For twenty countries, time-series data were obtained for the stock index underlying the first equity futures contract listed in the respective country. For the United States, we use data on the more popular S\&P 500 index instead of the Value Line index. In some cases, very little data exists

\footnotetext{
${ }^{3}$ The acronym refers to Baba, Engle, Kraft and Kroner, the original developers of the model.

${ }^{4}$ Datastream International, Inc.
} 
for the underlying index prior to the futures listing date, often because the index was designed specifically to underlie the futures contract and didn't exist very long prior to the introduction of the futures. Given the high correlations typically observed between different indices on the same market, we do not believe this to be a major problem. To illustrate, for Norway, we use data on the Oslo Stock Exchange (OSE) General Stock Index instead of the OBX index due to the lack of data on the OBX index prior to the listing date. Over a recent subsample, for which data are available on both indices, we calculated a correlation of .96 between them. Likewise, in Finland, we use the Helsinki Stock Exchange General Index (HEX) instead of the FOX index, and in the U.K. and Italy, we use market indexes calculated by Datastream due to insufficient daily data in the pre-event samples. ${ }^{5}$ In Japan, we used the first introduction of Nikkei 225 futures on the Singapore International Monetary Exchange (SIMEX) as our event date.

Daily data were obtained on Datastream's World Market Index from January 2, 1973 through December 31, 1997. For each country, we use all the stock index data available on Datastream between 1973 and 1997. In most cases, data are only available for part of this period. The time periods covered by our index data for each country, along with the number of daily observations in the pre- and post-event subsamples, are reported in Table 2.

In addition, we were able to collect daily contract volume and open interest data for seventeen of the countries in our sample. In most cases, these data were obtained from Datastream. Data from the Canadian market were provided by the Toronto Stock Exchange.

Table 3 reports the results of simple variance ratio tests, testing whether stock index volatility changes with the introduction of stock index futures trading. ${ }^{6}$ Results based on daily data are reported for various fixed event windows ranging from six months to five years. The final column reports results using all data available through Datastream.

\footnotetext{
${ }^{5}$ In the case of the U.K., weekly data are available for a large window prior to futures listing, but we felt that in order to make the result comparable to the other countries, we should use daily data.

${ }^{6}$ We conducted this test by calculating the variance of continuous daily returns using data before and after the date of futures introduction. The variance ratio has an $F$ distribution with degrees of freedom determined by the number of observations in the pre- and post-event samples.
} 
In this table, up and down arrows indicate volatility increases and decreases that are statistically significant at the $5 \%$ level, while plus and minus signs indicate changes that are not statistically significant. The results reported for Australia, Japan, Hong Kong and the U.S. correspond with the findings reported by Lee and Ohk (1992): no significant effect in Australia, results for Hong Kong that are sensitive to the choice of window size, and increased volatility in Japan and the United States. Despite the results for Japan and the United States, the overall impression given by Table 3 is that the introduction of futures trading is much more often associated with a volatility decrease than with an increase. Note that in nine countries, event windows may be selected to make the volatility effect of futures trading appear significantly positive or significantly negative. We do not place much confidence in these simple tests, inasmuch as they do not account for movements in the world market portfolio, autocorrelation due to infrequent trading, or conditional heteroskedasticity. These problems are addressed in the following sections.

\section{Volatility Effects of Futures Listing}

\section{A Empirical Framework for Univariate modeling}

We begin our analysis by modeling the time series of excess country returns net of the world market portfolio as a univariate GARCH process. This framework is parsimonious, allowing us to capture many of the salient features of the data, and to at least partially account for movements in the world market, in a model with relatively few parameters. Later, we will estimate a multivariate GARCH model that allows us a richer model of the joint dynamics of country-specific and world market returns.

Following Pagan and Schwert (1990) and Engle and $\mathrm{Ng}$ (1993), the first step in our univariate GARCH analysis is to remove from the time series any predictability associated with lagged returns or day-of-the-week effects. For each country, the following regression is estimated:

$$
R_{t}-R_{W t}=a_{0}+a_{1} R_{W t-1}+\sum_{j=2}^{5} a_{j} D A Y_{j}+u_{t}
$$


where $R_{t}$ is the daily return on the country's stock index and $R_{W t}$ is the daily return on the World Market Index on day $t, R_{W t-1}$ is the lagged return on the World Market Index, and $D A Y_{j}$ are day-of-the-week dummies for Tuesday through Friday.

We use the excess return relative to the world market index as our dependent variable and the lagged World Market Index return as an independent variable, in an effort to remove the effect of worldwide price movements on volatility. ${ }^{7}$ Regression results are reported in Table 4.

To correct for any remaining predictability, and to correct for spurious autocorrelation induced by non-synchronous trading, ${ }^{8}$ we perform the usual autocorrelation adjustment:

$$
u_{t}=b_{0}+\sum_{j=1}^{5} b_{j} u_{t-j}+\varepsilon_{t} .
$$

Table 5 reports parameter estimates for this equation. Following Engle and $\mathrm{Ng}$ (1993), we report Ljung-Box test statistics for twelfth-order serial correlation both in the residuals and their squares. The Ljung-Box statistics reported for the residual levels tell us that the regression model removes serial correlation in the stock return series in most of of the countries. At the $5 \%(1 \%)$ significance level there is no serial autocorrelation left in 9 (5) of 25 countries, and in several other cases the test statistic is only marginally significant. This suggests that the adjustment procedure removed the predictable part of the return series for most of the countries. The Ljung-Box test statistics for the squared residuals are highly significant in all cases, which is consistent with the existence of time varying volatility of index returns in all countries. We take this as evidence that some type of GARCH specification is necessary to properly model index returns in all countries.

Using $\left\{\varepsilon_{t}\right\}$ as our new return series, we proceed to test for the effect of futures introduction on the conditional volatility of the spot market, using various GARCH specifications.

\footnotetext{
${ }^{7}$ In separate tests not reported here, we included contemporaneous world returns on the right-hand side, allowing each country to have its own beta with respect to the world portfolio. These results, which are available on request, are similar to those reported here. We elected to use the current formulation because when contemporaneous variables are included in the first-stage regression, the GARCH volatility equation cannot strictly be interpreted as a conditional volatility.

${ }^{8}$ See Scholes and Williams (1977), Lo and MacKinlay (1988), Nelson (1991).
} 


\section{B Volatility Effect of Futures Introduction}

Having demonstrated the need to account for conditional heteroskedasticity in returns, we now address the issue of futures listing using a GARCH model. In GARCH modeling, the residuals $\varepsilon_{t}$ from the autoregression equation are assumed to be distributed $N\left(0, h_{t}\right)$, or alternatively $\varepsilon_{t}=$ $\epsilon_{t} \sqrt{h_{t}}$, where $\epsilon_{t}$ has a conditional distribution that is $N(0,1)$, and the conditional volatility $h_{t}$ depends on the GARCH specification.

In order to determine which GARCH specification we should use in our analysis, we conducted extensive tests, to see which form of the conditional volatility equation best seems to model the returns data. The results of these specification tests are not reported here, but are available on request. The main focus of this analysis was to determine whether we should use the symmetric GARCH model of Bollerslev (1986), in which positive and negative shocks of equal magnitude have the same effect on subsequent volatility, or a model where positive and negative shocks can have different effects. We tested the symmetric model and three alternative asymmetric models including the asymmetric GARCH (GJR-GARCH) model of Glosten, Jagannathan and Runkle (1993), the nonlinear GARCH (NGARCH) model of Engle and $\mathrm{Ng}$ (1993), and the exponential GARCH (EGARCH) model of Nelson (1991). Specification tests indicate that these asymmetric models fit the data better then the symmetric GARCH model, with the GRJ-GARCH performing marginally better than the others. Therefore, we base our main analysis on the GJR-GARCH model.

In this model, the conditional volatility equation takes the form:

$$
h_{t}=\alpha_{0}+\alpha_{1} h_{t-1}+\alpha_{2} \varepsilon_{t-1}^{2}+\alpha_{3} \max \left(0,-\varepsilon_{t-1}\right)^{2}
$$

In order to estimate the impact of futures introduction, we interact the GJR-GARCH conditional volatility equation with a multiplicative dummy, as follows:

$$
h_{t}=\left(1+\alpha_{M} D_{t}\right)\left[\alpha_{0}+\alpha_{1} h_{t-1}+\alpha_{2} \varepsilon_{t-1}^{2}+\alpha_{3} \max \left(0,-\varepsilon_{t-1}\right)^{2}\right]
$$

where $D_{t}$ takes on a value of zero prior to futures introduction and a value of one after futures 
introduction. A significant negative parameter estimate for $\alpha_{M}$ would indicate an decrease in the volatility associated with futures introduction.

Results are reported in Table 6. Defining statistical significance at the five percent level, we find that out of twenty-five countries, the coefficient $\alpha_{M}$ is positive and significant only for the United States and Japan, indicating an increase in conditional volatility associated with futures introduction in these countries. On the other hand, $\alpha_{M}$ is significantly negative for Australia, Austria, Belgium, Chile, Denmark, France, Germany, Hong Kong, Israel, Italy, Malaysia, Netherlands, Norway, South Africa, Switzerland and the United Kingdom, a total of sixteen countries, There is no significant effect in the remaining seven countries. The experience in the United States and Japan appears to be the exception, not the rule.

\section{Robustness Checks and Additional Tests}

This section summarizes various other specifications we tested, but did not report here because the results are substantively similar to those in table 6 . The results of all these tests are available on request.

Another approach to analyzing the effect of futures introduction on volatility is to put an additive dummy variable into the GARCH equation:

$$
h_{t}=\alpha_{0}+\alpha_{1} h_{t-1}+\alpha_{2} \varepsilon_{t-1}^{2}+\alpha_{3} \max \left(0,-\varepsilon_{t-1}\right)^{2}+\alpha_{A} D_{t}
$$

We repeated our analysis using this additive dummy specification for the GJR-GARCH model. In addition, we examined the standard $\operatorname{GARCH}(1,1)$ model of Bollerslev (1986), the nonlinear GARCH (NGARCH) model of Engle and $\mathrm{Ng}$ (1993), and the exponential GARCH (EGARCH) model of Nelson (1991). In some specifications, the volatility increase in Japan loses its significance, and in some specifications, other countries, including Canada, Hungary and Korea exhibit significant increases in conditional volatility. By and large, however, all of these specifications yield results supporting the same conclusion: outside of the United States and Japan, volatility has tended to decrease with futures listing, or at least to remain unchanged. 
In our analysis, we account for movements in the world index simply by estimating the dynamics of excess returns of the country index relative to the world market. Implicitly, this assumes that the beta of each country's return with respect to the world is one. In other results, reported in an earlier version of this paper, we also estimated a model where each country had its own beta. The results of this specification are similar to those reported here.

Some authors, such as Chan and Karolyi (1991) and Lee and Ohk (1992), have tested for more general structural changes in the GARCH equation at the time of futures listing by interacting a dummy variable separately for each term in the conditional volatility equation. By examining these coefficients, one can measure whether there is a change in the speed with which volatility shocks dissipate. We also estimated such a model for each country in our sample. Although some of the coefficients on the individual dummy variables were statistically significant, no clear pattern emerged across countries.

\section{The Effect of Futures Trading Activity}

If stock index futures markets truly have a stabilizing effect on cash markets, as our previous results suggest, then presumably the amount of stabilization would be related to the level of futures market activity. A naive approach to testing this would be to see if prices are more or less volatile in periods when futures trading is more active. The problem with this, of course, is that causality may go both ways: high spot market volatility may induce more people to trade futures.

Bessembinder and Seguin (1992) suggest a way to address this problem. Using an ARIMA model, they decompose the time series of futures trading volume and open interest into expected and unexpected components. Bursts of trading activity stimulated by unexpected price changes should be picked up in the unexpected component, while the expected component should reflect the "background" level of futures trading. They find that market volatility is positively related to the unexpected components of volume and open interest, reflecting the positive effect of volatility on volume, but that market volatility is negatively related to the expected component, suggesting 
an underlying stabilizing influence.

We follow a similar procedure using futures market trading volume and open interest data from seventeen of our twenty-five countries, for which data were available. First, we analyze the volume and open interest time series from each country to select an ARIMA model that appears to fit the data reasonably well. Restricting our attention to models with five or less autoregressive lags and five or less moving average lags, we select, on the basis of the autocorrelation structure, a different model for each time series. The models we selected, along with corresponding Ljung-Box(12) test statistics for model specification, are reported in Table 7.

We then use these models to decompose each time series into expected and unexpected components, and then insert them as additional explanatory variables in the GJR-GARCH conditional volatility equation:

$$
\begin{aligned}
h_{t} & =\alpha_{0}+\alpha_{1} h_{t-1}+\alpha_{2} \varepsilon_{t-1}^{2}+\alpha_{3} \max \left(0,-\varepsilon_{t-1}\right)^{2} \\
& +\alpha_{4} \text { ExpVol }+\alpha_{5} \text { UnexpVol }+\alpha_{6} \text { ExpOI }+\alpha_{7} \text { UnexpOI, }
\end{aligned}
$$

where ExpVol and UnexpVol are the expected and unexpected components of volume, and ExpOI and $U n \exp O I$ are the expected and unexpected components of open interest.

Estimation results are reported in Table 8. Out of the seventeen countries analyzed, the coefficient $\alpha_{7}$ on the unexpected component of open interest is negative in all seventeen, and statistically significant in eight. The coefficient $\alpha_{6}$ on the expected component of open interest is positive and significant only in Japan, and it is positive but not significant in the United States. The coefficient is negative in the remaining fifteen countries, significantly so in seven. Note that these results very closely correspond to those reported in our earlier analysis. We interpret this as additional evidence that it is in fact futures trading, not spuriously correlated factors that drives the results.

With respect to the unexpected component of futures trading volume, we find, like Bessembinder and Seguin (1992), that it has a positive effect on volatility. This is what we would expect to see if 
exogenous volatility events cause high trading volume. The expected component of futures volume, on the other hand, has no robust significant effect on volatility - there is a significant positive effect in Denmark, Germany and Hong Kong, a significant negative effect in Austria and the UK, and no significant effect in the other twelve countries.

\section{Modeling the Joint Dynamics of Country and World Volatility}

The univariate models we have employed above do not allow for time-varying conditional covariance between the country and world returns. If the conditional covariance changes systematically with the introduction of stock index futures, then our previous results may be biased.

In this section, we address this problem by estimating the joint dynamics of each country's return with the world market return in a multivariate GARCH framework that allows for time-varying conditional covariance. Because we wish to capture the dynamic interaction between world market volatility, country-specific volatility and conditional covariance, we use the BEKK specification of Engle and Kroner (1995). ${ }^{9}$ Unlike certain other well-known multivariate GARCH models, the BEKK model allows conditional variances and covariances to influence each other. ${ }^{10}$

For each country $i$, we estimate the following bivariate process:

$$
\begin{aligned}
& R_{i, t}=a_{0}+\sum_{j=1}^{5} a_{j} R_{i, t-j}+\sum_{k=2}^{5} b_{k} D A Y_{k}+\varepsilon_{i, t} \\
& R_{w, t}=w_{0}+\sum_{j=1}^{5} w_{j} R_{w, t-j}+\sum_{k=2}^{5} d_{k} D A Y_{k}+\varepsilon_{w, t}
\end{aligned}
$$

where the error terms are multivariate normal:

$$
\varepsilon_{\mathrm{t}} \mid \mathcal{F}_{t-1} \sim N\left(\mathbf{0}, \mathbf{H}_{\mathbf{t}}\right)
$$

\footnotetext{
${ }^{9}$ This model has also been used by Karolyi (1995) to model the joint dynamics of stock returns in Canada and the United States.

${ }^{10}$ For a comparison of BEKK and other multivariate GARCH models, see Kroner and Ng (1998).
} 
with conditional covariance matrix

$$
\mathbf{H}_{\mathrm{t}}=\mathbf{C}^{\prime} \mathbf{C}+\mathbf{A}^{\prime} \varepsilon_{\mathbf{t}-1} \varepsilon_{\mathrm{t}-1}^{\prime} \mathbf{A}+\mathbf{G}^{\prime} \mathbf{H}_{\mathrm{t}-1} \mathbf{G}+\Phi D_{t}
$$

In the mean equations, $R_{i, t}$ represents the log country index return, $R_{w, t}$ is the contemporaneous $\log$ world index return, and the variables $D A Y_{k}$ are day-of-the-week dummies for Tuesday through Friday. In the conditional variance equations, the coefficient matrix $\mathbf{C}$ represents a matrix of constants, A represents a matrix of ARCH coefficients, $\mathbf{G}$ represents a matrix of GARCH coefficients and $\Phi$ represents a matrix of dummy coefficients. Matrices $\mathbf{H}, \mathbf{C}, \mathbf{G}$, and $\Phi$ are symmetric. Our main purpose in using the multivariate GARCH model is to better correct for the effect of world market movements, not to test whether futures listing in individual countries influenced world market volatility. Thus, we did not include a dummy variable for futures listing in the conditional variance equation for world returns, and the element $\Phi_{22}$ is zero.

In summary,

$$
\begin{aligned}
\mathbf{H}_{\mathbf{t}}=\mathbf{C}^{\prime} \mathbf{C} & +\left[\begin{array}{ll}
a_{11} & a_{12} \\
a_{21} & a_{22}
\end{array}\right]^{\prime}\left[\begin{array}{cc}
\varepsilon_{1, t-1}^{2} & \varepsilon_{1, t-1} \varepsilon_{2, t-1} \\
\varepsilon_{2, t-1} \varepsilon_{1, t-1} & \varepsilon_{2, t-1}^{2}
\end{array}\right]\left[\begin{array}{ll}
a_{11} & a_{12} \\
a_{21} & a_{22}
\end{array}\right] \\
& +\left[\begin{array}{ll}
g_{11} & g_{12} \\
g_{12} & g_{22}
\end{array}\right]^{\prime} \mathbf{H}_{\mathbf{t}-1}\left[\begin{array}{ll}
g_{11} & g_{12} \\
g_{12} & g_{22}
\end{array}\right]+\left[\begin{array}{cc}
d_{11} & d_{12} \\
d_{12} & 0
\end{array}\right] D_{t}
\end{aligned}
$$

The interpretation of the dummy coefficient in a country's conditional variance equation is analogous to the dummy in the univariate GARCH equations analyzed above- a negative coefficient indicates that the introduction of futures corresponds to a volatility decrease. By including the dummy variable in the equation governing the conditional covariance of a country's return with the world market return, we are attempting to test whether futures introduction has any impact on the extent to which the country's stock market is integrated into the world market.

Maximum likelihood estimates of these parameters are reported in table 9. Examining the coefficients on the futures introduction dummy variable in the country-specific conditional volatility equation, we find a significant volatility increase in four countries (Germany, Japan, Hungary and Spain) and a significant decrease in twelve countries. Note that under this specification, for the 
United States the volatility effect is still positive but is no longer statistically significant. Although these results are not as one-sided as those from the GJR-GARCH model, we still observe a clear propensity for volatility to decrease after futures introduction.

Examining the dummy coefficients in the conditional covariance equations, we find that conditional covariance with the world market increases in twenty-one out of twenty-five countries, with statistical significance in thirteen cases. We may interpret this as evidence that futures markets contribute to an increase in the level of world market integration. On the other hand, we should interpret these results with caution, as over time we would expect countries to become more integrated with the world, with or without futures markets.

\section{Conclusion}

In this paper, we have examined the time series properties of returns in twenty-five markets around the world before and after the introduction of stock index futures.

First, in each country, we examined the time series of excess returns over the world market index using various GARCH models to account for asynchronous trading, conditional heteroskedasticity in returns, and an asymmetric response to positive and negative news. Our results indicate that in the largest two markets, the United States and Japan, volatility may have increased after the listing of stock index futures. On the other hand, volatility decreased or stayed roughly the same in most of the other countries in our sample, with statistically significant decreases in many cases. This result appears to be robust to model specification, holding for different specifications of the dummy variable and for GARCH specifications, including models that allow for asymmetric responses to good and bad news.

Next, using a procedure inspired by Bessembinder and Seguin (1992), we found that in most countries, volatility tends to be lower in periods when open interest in stock index futures is high. The only two cases where we find the opposite result are the United States and Japan, reinforcing our previous results. In some cases, volatility is higher in periods when futures volume is high, but 
this is driven by the unexpected component of volume, not the expected component.

Finally, we extended our analysis to a multivariate framework which allows for the possibility of volatility spillover and time-varying conditional covariance between country-specific and world returns. In this framework, the basic result of our previous analysis is preserved-country-specific conditional variance is likely to decline with the introduction of stock index futures. We also document that the markets in most countries are significantly more integrated with the world market after the introduction of stock index futures.

We do not deny that these results may be influenced by other factors, and, as always, advocate caution in interpreting empirical results. In particular, several points should be considered that may confound the interpretation of our results, and those of all the previous papers in this literature.

First, the listing of index futures is not an entirely exogenous event. The listing process involves many decisions made by exchange officials and regulators, who may be influenced by recent or anticipated market conditions. For example, the reluctance of regulators to approve the introduction of index futures during periods of political uncertainty may introduce a selection bias.

Second, because the events in our sample are not independent draws from an homogeneous population, we cannot really interpret this as we would a traditional event study. ${ }^{11}$ Different countries have different contract designs, trading mechanisms, and regulatory environments. Some countries have listed index options in addition to index futures, and others have not. Some countries have competing offshore contracts, and others do not. Moreover, the events in our sample are clustered in time, with a group of English-speaking developed countries listing in the early 1980's, a group of Western European and other developed markets listing in the late 1980's, and emerging markets listing in the 1990's.

Third, it should be noted that a relatively long time series is required to obtain reliable GARCH parameter estimates. In some cases, particularly for the most recent listings in our sample, our window length may be too short. This may explain the unusual parameter estimates reported for

\footnotetext{
${ }^{11}$ We thank Andrew Karolyi for useful comments on this issue.
} 
Hungary and Portugal.

Despite these inherent difficulties, the results we have reported here do present a relatively consistent picture, which appears to be robust to model specification: in less-developed markets, the introduction of stock index futures contributes to a decrease in conditional variance. 


\section{References}

[1] Antoniou, Antonios, Phil Holmes, and Richard Priestley, 1998, The Effects of Stock Index Futures Trading on Stock Index Volatility: An Anslysis of the Asymmetric Response of Volatility to News, Journal of Futures Markets 18, 151-166.

[2] Bessembinder, Hendrik and Paul J. Seguin, 1992, Futures-Trading Activity and Stock Price Volatility, Journal of Finance 47, 2015-2034.

[3] Bollerslev, T. 1986, Generalized Autoregressive Conditional Heteroscedasticity, Journal of Econometrics $31,307-327$

[4] Chan, K.C. and G. Andrew Karolyi, 1991, The Volatility of the Japanese Stock Market: Evidence from 1977 to 1990, in Japanese Financial Market Research, W.T.Ziemba, W. Bailey and Y. Hamao, eds., Elsevier.

[5] Damodaran, Aswath and Marti G. Subrahmanyam, 1992, The Effects of Derivative Securities on the Markets for the Underlying Assets in the United States: A Survey, Financial Markets, Institutions \& Instruments 1, 1-22.

[6] Engle, Robert F. and Kenneth F. Kroner, 1995, Multivariate Simultaneous Generalized ARCH, Econometric Theory 11, 122-150.

[7] Engle, Robert and Joseph Mezrich, 1995, Grappling with GARCH, Risk, 8, 112-117.

[8] Engle, Robert and Victor Ng, 1993, Measuring and Testing the Impact of News on Volatility, Journal of Finance 48, 1749-1778.

[9] Glosten, Lawrence R., Ravi Jagannathan and David E. Rundle, 1993, On the Relation between the Expected Value and the Volatility of the Nominal Excess Return on Stocks, Journal of Finance 48, 1779-1801. 
[10] Hodges, Stewart, 1992, Do Derivative Instruments Increase Market Volatility?, 1992, Options: Recent Advances in Theory and Practice vII (chapter 12), Stewart Hodges, ed., Manchester University Press.

[11] Karolyi, G. Andrew, 1995, A Multivariate GARCH Model of International Transmissions of Stock Returns and Volatility: The Case of the United States and Canada, Journal of Business \& Economic Statistics 13, 11-25.

[12] Kroner, Kenneth F. and Victor K. Ng, 1998, Modeling Asymmetric Comovements of Asset Returns, Review of Financial Studies 11, 817-844.

[13] Lee, Sang Bin and Ki Yool Ohk, 1992, Stock Index Futures Listing and Structural Change in Time-Varying Volatility, Journal of Futures Markets 12, 493-509.

[14] Lo, Andrew and Craig MacKinlay, 1988, Stock Market Prices Do Not Follow Random Walks: Evidence From Simple Specification Test, Review of Financial Studies 1, 41-66.

[15] Mayhew, Stewart, 1999, The Impact of Derivatives on Cash Markets: What Have We Learned?, Working paper, Purdue University.

[16] Nelson, D. 1991, Conditional Heteroscedasticity in Asset Returns: A New Approach, Econometrica 59, 347-370.

[17] Pagan, A. and G. W. Schwert, 1990, Alternative Models For Conditional Stock Volatility, Journal of Econometrics 45, 267-290.

[18] Rhode, William, 1997, Risk in an Era of Reform, AsiaRisk (Supplement to Risk), October $19-23$.

[19] Scholes, Myron and J. Williams, 1977, Estimating Betas from Nonsynchronous Data, Journal of Financial Economics 5, 309-327. 
[20] Stewart, Jules and Andrew Priest, 1997, Exchange of Fortunes, LatinRisk (Latin America Supplement to Risk), October 21-23.

[21] Sutcliffe, Charles, 1997, Stock Index Futures: Theories and International Evidence, 2nd ed., International Thomson Business Press. 
APPENDIX

\section{A Information About Stock Index Futures Markets}

For information on plans for derivatives trading in Latin markets, see Stewart and Priest (1997).

For a discussion of plans for derivatives in India, see Rhode (1997). More information may be available on the following web sites:

\begin{tabular}{|c|c|c|}
\hline Country & Source of Information & URL \\
\hline \hline Czech Republic & Prague Stock Exchange & www.pse.cz/defaulten.htm \\
\hline India & National Stock Exchange & www.nseindia.com \\
\hline Indonesia & Surabaya Stock Exchange & www.bes.co.id \\
\hline Mexico & Mexican Stock Exchange & www.bmv.com.mx \\
\hline Slovakia & Federation of Euro Asian Stock Exchanges & www.feas.org/newsltr.htm \\
\hline Turkey & Istanbul Stock Exchange & www.ise.org/ \\
\hline
\end{tabular}


Table 1:

\section{Launch Dates for Index Futures Contracts}

Initial trading dates for various Index Futures contracts. Sources: information published by the individual exchanges, telephone conversations with exchange officials, Futures Industry Association Fact Book. It should be noted that the trading of Japanese stock index futures initiated in Singapore.

\begin{tabular}{|c|c|c|}
\hline Country & Underlying Index & Launch Date \\
\hline \multirow[t]{2}{*}{ United States } & Value Line & 24 Feb 1982 \\
\hline & S\&P 500 & 21 Apr 1982 \\
\hline Australia & All Ordinaries & 16 Feb 1983 \\
\hline UK & FT-SE 100 & 03 May 1984 \\
\hline Canada & TSE 300 & $16 \operatorname{Jan} 1984$ \\
\hline Brazil & BOVESPA & 14 Feb 1986 \\
\hline Hong Kong & Hang Seng & 06 May 1986 \\
\hline Japan (SIMEX) & Nikkei 225 & 03 Sep 1986 \\
\hline (Osaka) & OSE 50 & 09 Jun 1987 \\
\hline (Osaka) & Nikkei 225 & 03 Sep 1988 \\
\hline (Tokyo) & Topix & 03 Sep 1988 \\
\hline New Zealand & Barclay Share & Jan 1987 \\
\hline Sweden & $\mathrm{OMX}$ & 03 Apr 1987 \\
\hline Finland & FOX & 02 May 1988 \\
\hline Netherlands & AEX & 24 Oct 1988 \\
\hline France & CAC 40 & 09 Nov 1988 \\
\hline Denmark & KFX & $07 \overline{\text { Dec } 1989}$ \\
\hline South Africa & All Share & 30 Apr 1990 \\
\hline Switzerland & SMI & 09 Nov 1990 \\
\hline Germany & $\mathrm{DAX}$ & 23 Nov 1990 \\
\hline Chile & IPSA & Dec 1990 \\
\hline Spain & IBEX 35 & $14 \operatorname{Jan} 1992$ \\
\hline Austria & ATX & 07 Aug 1992 \\
\hline Norway & OBX & 04 Sep 1992 \\
\hline Belgium & BEL 20 & 29 Oct 1993 \\
\hline Italy & MIB 30 & 28 Nov 1994 \\
\hline Hungary & $\overline{\mathrm{BSI}}$ & 31 Mar 1995 \\
\hline Israel & Maof 25 & 27 Oct 1995 \\
\hline Malaysia & KLCI & 15 Dec 1995 \\
\hline Korea & KOSPI 200 & 03 May 1996 \\
\hline Portugal & PSI-20 & 20 Jun 1996 \\
\hline Russia & RTS & Mar 1997 \\
\hline Venezuela & IBC & 05 Sep 1997 \\
\hline Poland & WIG20 & $16 \operatorname{Jan} 1998$ \\
\hline
\end{tabular}


Table 2:

\section{Data Periods}

Description of the data period used for each country, including the number of daily return observations before and after stock index futures listing.

\begin{tabular}{|c|c|c|c|}
\hline Country & Data Period & Obs. Pre- & Obs. Post- \\
\hline Australia & 02 Jan $1980-31$ Dec 1997 & 779 & 3572 \\
\hline Austria & 20 Nov $1987-31$ Dec 1997 & 1162 & 1334 \\
\hline Belgium & 02 Jan $1990-31$ Dec 1997 & 941 & 1037 \\
\hline Canada & 02 Jan $1973-31$ Dec 1997 & 2740 & 3516 \\
\hline Chile & 02 Jan $1987-31$ Dec 1997 & 879 & 1741 \\
\hline Denmark & 10 Dec $1979-31$ Dec 1997 & 2476 & 2037 \\
\hline Finland & 02 Jan $1987-31$ Dec 1997 & 333 & 2424 \\
\hline France & 09 Jul $1987-31$ Dec 1997 & 330 & 2270 \\
\hline Germany & 21 Nov $1977-31$ Dec 1997 & 3215 & 1771 \\
\hline Japan & 04 Jan $1980-31$ Dec 1997 & 2098 & 2298 \\
\hline Hong Kong & 02 Jan $1973-31$ Dec 1997 & 3263 & 2888 \\
\hline Hungary & 02 Jan $1991-31$ Dec 1997 & 1056 & 674 \\
\hline Israel & 02 Jan $1992-31$ Dec 1997 & 928 & 527 \\
\hline Italy & 02 Jan $1973-31$ Dec 1997 & 5507 & 780 \\
\hline Korea & 03 Jan $1990-31$ Dec 1997 & 1540 & 398 \\
\hline Malaysia & 02 Jan $1980-31$ Dec 1997 & 3902 & 508 \\
\hline Netherlands & 03 Jan $1983-31$ Dec 1997 & 1402 & 2313 \\
\hline Norway & 03 Jan $1983-31$ Dec 1997 & 2418 & 1333 \\
\hline Portugal & 01 Jan $1993-31$ Dec 1997 & 853 & 376 \\
\hline South Africa & 10 Apr $1985-31$ Dec 1997 & 1136 & 1891 \\
\hline Spain & 06 Jan 1987- 31 Dec 1997 & 1238 & 1501 \\
\hline Sweden & 02 Jan $1986-31$ Dec 1997 & 311 & 2694 \\
\hline Switzerland & 01 Jul $1988-31$ Dec 1997 & 590 & 1792 \\
\hline United Kingdom & 02 Jan $1973-31$ Dec 1997 & 2871 & 3485 \\
\hline United States & 02 Jan $1973-31$ Dec 1997 & 2340 & 3967 \\
\hline
\end{tabular}


Table 3:

\section{Variance Ratio Test Results}

Results of variance ratio tests of whether stock index volatility changes with the introduction of stock index futures trading. Results are reported for pre- and postevent windows ranging from six months to sixty months, and for the entire sample. An up (down) arrow indicates a statistically significant increase (decrease) at the .05 level. Plusses and minuses indicate changes that were not statistically significant. A blank indicates that either in the pre- or post-event period not enough data are available to fill out the designated event window. In Japan, we used the first listing date for stock index futures on the Singapore Exchange.

\begin{tabular}{|l|c|c|c|c|c|c|}
\hline Country & Index & $6 \mathrm{M}$ & $12 \mathrm{M}$ & $24 \mathrm{M}$ & $60 \mathrm{M}$ & All Data \\
\hline \hline Australia & All Ordinaries & + & - & $\downarrow$ & & + \\
\hline Austria & ATX & $\uparrow$ & - & $\downarrow$ & & $\downarrow$ \\
\hline Belgium & BEL 20 & - & + & $\downarrow$ & & $\downarrow$ \\
\hline Canada & TSE 300 & - & - & $\downarrow$ & $\downarrow$ & $\downarrow$ \\
\hline Chile & IPSA & $\uparrow$ & $\uparrow$ & $\uparrow$ & & $\downarrow$ \\
\hline Denmark & KFX & $\downarrow$ & $\downarrow$ & $\downarrow$ & $\downarrow$ & $\downarrow$ \\
\hline Finland & FOX/HEX & $\downarrow$ & $\downarrow$ & & & - \\
\hline France & CAC-40 & $\downarrow$ & $\downarrow$ & & & $\downarrow$ \\
\hline Germany & DAX 30 & $\downarrow$ & $\downarrow$ & $\downarrow$ & & $\downarrow$ \\
\hline Hong Kong & Hang Seng & - & - & $\uparrow$ & - & $\downarrow$ \\
\hline Hungary & BUX & $\downarrow$ & $\uparrow$ & - & & $\uparrow$ \\
\hline Israel & Maof 25 & + & $\downarrow$ & $\downarrow$ & & $\downarrow$ \\
\hline Italy & MIB 30 & - & $\downarrow$ & $\downarrow$ & & $\downarrow$ \\
\hline Japan (SIMEX) & Nikkei 225 & $\uparrow$ & $\uparrow$ & $\uparrow$ & $\uparrow$ & $\uparrow$ \\
\hline Korea & KOSPI 200 & + & $\uparrow$ & & & $\uparrow$ \\
\hline Malaysia & KLCI & + & $\downarrow$ & $\uparrow$ & & $\uparrow$ \\
\hline Netherlands & AEX & $\downarrow$ & $\downarrow$ & $\downarrow$ & $\downarrow$ & $\downarrow$ \\
\hline Norway & OBX/OSE & + & $\downarrow$ & $\downarrow$ & $\downarrow$ & $\downarrow$ \\
\hline Portugal & PSI-20 & $\downarrow$ & $\uparrow$ & & & $\uparrow$ \\
\hline South Africa & All Share & $\downarrow$ & $\downarrow$ & $\downarrow$ & $\downarrow$ & $\downarrow$ \\
\hline Spain & IBEX 35 & $\downarrow$ & $\uparrow$ & $\downarrow$ & $\downarrow$ & $\downarrow$ \\
\hline Sweden & OMX & $\downarrow$ & $\uparrow$ & & & $\downarrow$ \\
\hline Switzerland & SMI & $\downarrow$ & $\downarrow$ & $\downarrow$ & & $\downarrow$ \\
\hline United Kingdom & FT-SE 100 & $\uparrow$ & $\uparrow$ & - & $\uparrow$ & $\downarrow$ \\
\hline United States & S\&P 500 & $\uparrow$ & $\uparrow$ & + & $\uparrow$ & $\uparrow$ \\
\hline & & & & & & \\
\hline
\end{tabular}


Table 4:

\section{Coefficients from the first-stage regression}

Results from the first-stage regression of country-specific returns on lagged world market index and day-of-the-week dummies. The model is

$$
R_{t}-R_{W t}=a_{0}+a_{1} R_{W t-1}+\sum_{j=2}^{5} a_{j} D A Y_{j}+u_{t}
$$

where $R_{t}$ is the daily return on the country's stock index and $R_{W t}$ is the daily return on the World Market Index on day $t, R_{W t-1}$ is the lagged return on the World Market Index, and $D A Y_{j}$ are day-of-the-week dummies for Tuesday through Friday. t-statistics are shown in parentheses.

\begin{tabular}{|l|c|c|c|c|c|c|}
\hline Country & Intercept & $R_{W t-1}$ & Tuesday & Wednesday & Thursday & Friday \\
\hline \hline Australia & 0.03713 & 0.37582 & -0.12036 & -0.08899 & -0.05075 & -0.02427 \\
& $(1.12)$ & $(18.47)$ & $(-2.60)$ & $(-1.92)$ & $(-1.10)$ & $(-0.52)$ \\
\hline Austria & 0.03977 & 0.18755 & -0.08241 & -0.05627 & -0.0206 & -0.01558 \\
& $(0.74)$ & $(5.17)$ & $(-1.09)$ & $(-0.75)$ & $(-0.27)$ & $(-0.20)$ \\
\hline Belgium & -0.03235 & -0.09882 & 0.02773 & 0.0515 & 0.08215 & 0.04227 \\
& $(-0.81)$ & $(-3.73)$ & $(0.50)$ & $(0.92)$ & $(1.46)$ & $(0.75)$ \\
\hline Canada & -0.03279 & -0.02523 & 0.02417 & 0.01898 & 0.04067 & 0.0617 \\
& $(-1.74)$ & $(-2.16)$ & $(0.93)$ & $(0.73)$ & $(1.56)$ & $(2.36)$ \\
\hline Chile & -0.02036 & -0.09196 & 0.06182 & 0.15283 & 0.13664 & 0.35277 \\
& $(-0.31)$ & $(-2.35)$ & $(0.66)$ & $(1.62)$ & $(1.46)$ & $(3.73)$ \\
\hline Denmark & 0.07744 & 0.0316 & -0.08543 & -0.09859 & -0.0349 & -0.06804 \\
& $(2.15)$ & $(1.42)$ & $(-1.69)$ & $(-1.95)$ & $(0.68)$ & $(-1.34)$ \\
\hline Finland & 0.01714 & 0.05714 & -0.07254 & -0.03055 & 0.04796 & 0.01671 \\
& $(0.035)$ & $(1.92)$ & $(-1.05)$ & $(-0.44)$ & $(0.69)$ & $(0.24)$ \\
\hline France & -0.13878 & -0.06692 & 0.19068 & 0.17274 & 0.19733 & 0.14794 \\
& $(-2.72)$ & $(-2.23)$ & $(2.69)$ & $(2.44)$ & $(2.78)$ & $(2.08)$ \\
\hline Germany & 0.00181 & 0.00702 & -0.00736 & -0.01063 & 0.00782 & -0.03405 \\
& $(0.05)$ & $(0.32)$ & $(-0.15)$ & $(-0.22)$ & $(0.16)$ & $(-0.70)$ \\
\hline Hong Kong & -0.11824 & 0.33057 & 0.08932 & 0.21506 & 0.06375 & 0.21209 \\
& $(-2.09)$ & $(9.41)$ & $(1.14)$ & $(2.74)$ & $(0.81)$ & $(2.69)$ \\
\hline Hungary & 0.09398 & 0.30634 & -0.0519 & 0.074 & -0.1148 & -0.0072 \\
& $(1.17)$ & $(5.25)$ & $(-0.46)$ & $(0.65)$ & $(-1.02)$ & $(-0.06)$ \\
\hline Israel & -0.0261 & 0.09774 & 0.136 & 0.0891 & 0.1029 & -0.0052 \\
& $(-0.27)$ & $(1.29)$ & $(0.99)$ & $(0.64)$ & $(0.75)$ & $(-0.04)$ \\
\hline Italy & -0.03453 & -0.0395 & -0.02546 & 0.01258 & 0.12575 & 0.14268 \\
& $(-0.89)$ & $(-1.60)$ & $(-0.47)$ & $(0.23)$ & $(2.30)$ & $(2.61)$ \\
\hline
\end{tabular}


Table 4: Continued

\section{Coefficients from the first-stage regression}

Results from the first-stage regression of country-specific returns on lagged world market index and day-of-the-week dummies. The model is

$$
R_{t}-R_{W t}=a_{0}+a_{1} R_{W t-1}+\sum_{j=2}^{5} a_{j} D A Y_{j}+u_{t}
$$

where $R_{t}$ is the daily return on the country's stock index and $R_{W t}$ is the daily return on the World Market Index on day $t, R_{W t-1}$ is the lagged return on the World Market Index, and $D A Y_{j}$ are day-of-the-week dummies for Tuesday through Friday. t-statistics are shown in parentheses.

\begin{tabular}{|l|c|c|c|c|c|c|}
\hline Country & Intercept & $R_{W t-1}$ & Tuesday & Wednesday & Thursday & Friday \\
\hline \hline Japan & -0.02319 & 0.12491 & -0.03524 & 0.1518 & 0.02208 & -0.02629 \\
& $(-0.68)$ & $(6.10)$ & $(-0.73)$ & $(0.32)$ & $(0.46)$ & $(-0.55)$ \\
\hline Korea & -0.11001 & 0.06893 & -0.0134 & 0.1928 & -0.0294 & 0.0696 \\
& $(-1.25)$ & $(1.19)$ & $(-0.11)$ & $(1.55)$ & $(-0.24)$ & $(0.56)$ \\
\hline Malaysia & -0.12483 & 0.11017 & -0.00552 & 0.1473 & 0.16837 & 0.19752 \\
& $(-2.57)$ & $(3.69)$ & $(-0.08)$ & $(2.16)$ & $(2.47)$ & $(2.89)$ \\
\hline Netherlands & -0.03254 & -0.06764 & 0.08861 & 0.08935 & -0.0007 & 0.07009 \\
& $(-0.81)$ & $(-2.72)$ & $(1.58)$ & $(1.60)$ & $(-0.01)$ & $(1.24)$ \\
\hline Norway & -0.00539 & 0.11298 & -0.0183 & -0.01034 & 0.04217 & 0.10545 \\
& $(-0.13)$ & $(4.33)$ & $(-0.31)$ & $(-0.18)$ & $(0.72)$ & $(1.80)$ \\
\hline Portugal & 0.0026 & 0.08223 & 0.0076 & 0.07838 & 0.06654 & 0.03059 \\
& $(0.05)$ & $(1.84)$ & $(0.10)$ & $(1.02)$ & $(0.86)$ & $(0.39)$ \\
\hline South Africa & -0.03475 & 0.0238 & 0.00832 & 0.14594 & 0.07647 & -0.013 \\
& $(-0.68)$ & $(0.84)$ & $(0.12)$ & $(2.04)$ & $(1.06)$ & $(-0.18)$ \\
\hline Spain & 0.12966 & 0.12702 & -0.12834 & -0.22861 & -0.14339 & -0.10601 \\
& $(2.67)$ & $(4.32)$ & $(-1.87)$ & $(-3.33)$ & $(-2.08)$ & $(-1.54)$ \\
\hline Sweden & -0.01588 & 0.06626 & 0.02283 & 0.02446 & 0.06669 & 0.06367 \\
& $(-0.32)$ & $(2.21)$ & $(0.33)$ & $(0.35)$ & $(0.95)$ & $(0.91)$ \\
\hline Switzerland & -0.01227 & -0.03589 & 0.00782 & 0.09924 & 0.07047 & 0.04842 \\
& $(-0.29)$ & $(-1.29)$ & $(0.13)$ & $(1.66)$ & $(1.17)$ & $(0.80)$ \\
\hline United Kingdom & -0.07092 & 0.02278 & 0.15129 & 0.05893 & 0.06196 & 0.1269 \\
& $(-2.55)$ & $(1.30)$ & $(3.91)$ & $(1.53)$ & $(1.61)$ & $(3.28)$ \\
\hline United States & 0.03189 & -0.16465 & -0.00269 & -0.04298 & -0.03865 & -0.03503 \\
& $(1.67)$ & $(-13.60)$ & $(-0.10)$ & $(-1.61)$ & $(-1.44)$ & $(-1.31)$ \\
\hline
\end{tabular}


Table 5:

\section{Coefficients from the residual autoregression}

Estimated parameters of the residual autoregression

$$
u_{t}=b_{0}+\sum_{j=1}^{5} b_{j} u_{t-j}+\varepsilon_{t}
$$

where $u_{t}$ is the residual from regression 1 . t-statistics are shown in parentheses. Ljung-Box statistics testing for 12 th order serial autocorrelation in $\varepsilon$ and $\varepsilon^{2}$ are also reported.

\begin{tabular}{|l|c|c|c|c|c|c|c|c|}
\hline Country & Constant & $b_{1}$ & $b_{2}$ & $b_{3}$ & $b_{4}$ & $b_{5}$ & $\begin{array}{c}\text { LBQ(12) } \\
\text { (Levels) }\end{array}$ & $\begin{array}{c}\text { LBQ(12) } \\
\text { (Squares) }\end{array}$ \\
\hline \hline Australia & 0.0232 & 0.00006 & 0.1012 & -0.0134 & 0.0253 & -0.0181 & 8.4 & 630.27 \\
& $(1.56)$ & $(0.00)$ & $(6.81)$ & $(-0.90)$ & $(-1.21)$ & $(1.69)$ & & \\
\hline Austria & 0.031 & -0.00009 & 0.2276 & -0.021 & -0.0246 & -0.0125 & $20.6^{* *}$ & 438.65 \\
& $(1.55)$ & $(-0.00)$ & $(11.36)$ & $(-1.02)$ & $(-1.20)$ & $(-0.61)$ & & \\
\hline Belgium & -0.0358 & 0 & 0.0274 & 0.066 & 0.0399 & -0.0026 & 6.9 & 271.55 \\
& $(-1.59)$ & $(0.0)$ & $(1.22)$ & $(2.93)$ & $(1.77)$ & $(-0.12)$ & & \\
\hline Canada & 0.0104 & 0 & 0.0808 & -0.0023 & 0.01 & 0.0272 & 7.9 & 639.94 \\
& $(0.82)$ & $(-0.0)$ & $(6.39)$ & $(-0.18)$ & $(0.79)$ & $(2.14)$ & & \\
\hline Chile & -0.00011 & 0.1981 & -0.0534 & -0.0394 & 0.0598 & -0.005 & 7.1 & 176.466 \\
& $(-0.00)$ & $(10.12)$ & $(-2.68)$ & $(-1.98)$ & $(3.00)$ & $(-0.26)$ & & \\
\hline Denmark & -0.00001 & 0.0947 & -0.0037 & -0.0017 & -0.0402 & 0.0051 & 7.4 & 41.96 \\
& $(-0.00)$ & $(6.36)$ & $(-0.25)$ & $(-0.11)$ & $(-2.69)$ & $(0.34)$ & & \\
\hline Finland & 0.00005 & 0.1764 & 0.0001 & 0.0052 & 0.0153 & 0.022 & 10.2 & 340.722 \\
& $(0.00)$ & $(9.25)$ & $(0.00)$ & $(0.27)$ & $(0.79)$ & $(1.15)$ & & \\
\hline France & 0.00002 & -0.0797 & 0.0533 & -0.0059 & 0.0016 & 0.014 & $15.5^{*}$ & 917.54 \\
& $(0.00)$ & $(-4.06)$ & $(2.70)$ & $(-0.30)$ & $(0.08)$ & $(0.71)$ & & \\
\hline Germany & 0.00001 & -0.0307 & -0.0001 & 0.02 & -0.0164 & 0.0141 & 4.8 & 438.591 \\
& $(0.00)$ & $(-2.16)$ & $(-0.01)$ & $(1.41)$ & $(-1.16)$ & $(1.00)$ & & \\
\hline Hkong & -0.00003 & 0.0432 & -0.0237 & 0.0601 & -0.0093 & -0.0183 & $18.9^{* *}$ & 1083.33 \\
& $(-0.00)$ & $(3.39)$ & $(-1.85)$ & $(4.71)$ & $(-0.73)$ & $(-1.43)$ & & \\
\hline Hungary & 0.0003 & 0.1301 & 0.0531 & 0.007 & -0.0113 & 0.0141 & $33.8^{* *}$ & 727.973 \\
& $(0.01)$ & $(5.40)$ & $(2.19)$ & $(0.29)$ & $(-0.46)$ & $(0.59)$ & & \\
\hline Israel & -0.00008 & -0.0174 & -0.0365 & -0.0207 & 0.0117 & -0.0581 & $16.3^{*}$ & 223.239 \\
& $(-0.00)$ & $(-0.66)$ & $(-1.39)$ & $(-0.79)$ & $(0.45)$ & $(-2.22)$ & & \\
\hline Italy & 0.00001 & 0.1592 & -0.0717 & 0.0392 & 0.0013 & -0.001 & 12.9 & 2050.29 \\
& $(0.00)$ & $(12.61)$ & $(-5.61)$ & $(3.06)$ & $(0.10)$ & $(-0.08)$ & & \\
\hline
\end{tabular}


Table 5: Continued

Coefficients from the residual autoregression

Estimated parameters of the residual autoregression

$$
u_{t}=b_{0}+\sum_{j=1}^{5} b_{j} u_{t-j}+\varepsilon_{t} .
$$

where $u_{t}$ is the residual from regression 1. t-statistics are shown in parentheses. Ljung-Box statistics testing for 12 th order serial autocorrelation in $\varepsilon$ and $\varepsilon^{2}$ are also reported.

\begin{tabular}{|l|c|c|c|c|c|c|c|c|}
\hline Country & Constant & $b_{1}$ & $b_{2}$ & $b_{3}$ & $b_{4}$ & $b_{5}$ & $\begin{array}{c}\text { LBQ(12) } \\
\text { (Levels) }\end{array}$ & $\begin{array}{c}\text { LBQ(12) } \\
\text { (Squares) }\end{array}$ \\
\hline \hline Japan & -0.00004 & -0.0792 & -0.0668 & 0.0229 & -0.0021 & -0.0061 & 8.1 & 801.76 \\
& $(0.00)$ & $(-5.24)$ & $(-4.41)$ & $(1.51)$ & $(-0.14)$ & $(-0.40)$ & & \\
\hline Korea & 0.00038 & -0.0021 & -0.0422 & -0.0219 & -0.0372 & -0.0528 & 11.9 & 1009.59 \\
& $(0.01)$ & $(-0.09)$ & $(-1.85)$ & $(-0.96)$ & $(-1.62)$ & $(-2.30)$ & & \\
\hline Malaysia & 0.00003 & 0.1209 & 0.007 & -0.0114 & 0.0065 & 0.0105 & 10.9 & 1352.07 \\
& $(0.00)$ & $(8.02)$ & $(0.46)$ & $(-0.75)$ & $(0.43)$ & $(0.70)$ & & \\
\hline Netherlands & 0.00006 & -0.0971 & 0.0274 & 0.0257 & -0.0166 & 0.0453 & $21.4^{* *}$ & 780.3 \\
& $(0.00)$ & $(-5.92)$ & $(1.66)$ & $(1.56)$ & $(-1.01)$ & $(2.76)$ & & \\
\hline Norway & 0.00001 & 0.1182 & -0.0068 & -0.0129 & -0.0466 & 0.0373 & $14.9 *$ & 501.91 \\
& $(0.00)$ & $(7.24)$ & $(-0.41)$ & $(-0.78)$ & $(-2.84)$ & $(2.28)$ & & \\
\hline Portugal & -0.00004 & 0.1516 & 0.049 & -0.0522 & -0.0074 & -0.0127 & 13.8 & 154.161 \\
& $(-0.00)$ & $(5.30)$ & $(1.69)$ & $(-1.80)$ & $(-0.26)$ & $(-0.44)$ & & \\
\hline South Africa & -0.00002 & 0.0834 & -0.0252 & 0.0018 & -0.0218 & -0.0308 & 9.6 & 38.1064 \\
& $(-0.00)$ & $(4.58)$ & $(-1.38)$ & $(0.10)$ & $(-1.20)$ & $(-1.69)$ & & \\
\hline Spain & -0.00008 & 0.0915 & 0.0149 & -0.054 & 0.0364 & -0.0186 & $18.4^{*}$ & 782.843 \\
& $(-0.00)$ & $(4.78)$ & $(0.78)$ & $(-2.82)$ & $(1.89)$ & $(-0.97)$ & & \\
\hline Sweden & 0.00018 & 0.0555 & 0.0252 & -0.0135 & 0.0106 & 0.0178 & 11.6 & 715.95 \\
& $(0.01)$ & $(3.04)$ & $(1.38)$ & $(-0.74)$ & $(0.58)$ & $(0.97)$ & & \\
\hline Switzerland & 0 & -0.02 & 0.0089 & -0.0404 & 0.0052 & -0.0248 & 7.2 & 56.3926 \\
& $(0.00)$ & $(-0.98)$ & $(0.43)$ & $(-1.97)$ & $(0.25)$ & $(-1.21)$ & & \\
\hline UK & -0.00001 & 0.0761 & 0.0107 & 0.0101 & 0.004 & -0.0099 & 13.5 & 4791.4 \\
& $(-0.00)$ & $(6.06)$ & $(0.85)$ & $(0.81)$ & $(0.32)$ & $(-0.79)$ & & \\
\hline US & -0.000025 & -0.1303 & -0.0076 & -0.0187 & -0.0513 & -0.0097 & $20.2^{* *}$ & 1252.86 \\
& $(-0.00)$ & $(-10.34)$ & $(-0.60)$ & $(-1.48)$ & $(-4.04)$ & $(-0.77)$ & & \\
\hline & & & & & & & &
\end{tabular}


Table 6:

\section{Effect of Futures Introduction on GJR-GARCH Volatility}

Constrained Maximum Likelihood parameter estimates are reported for the GJRGARCH model with a multiplicative dummy:

$$
h_{t}=\left(1+\alpha_{M} D_{t}\right)\left[\alpha_{0}+\alpha_{1} h_{t-1}+\alpha_{2} \varepsilon_{t-1}^{2}+\alpha_{3} \max \left(0,-\varepsilon_{t-1}\right)^{2}\right]
$$

where $\varepsilon_{t}$ is the residual from autoregression 2 , and $\alpha_{M}$ is a dummy variable equal to zero before and one after the futures introduction. Standard errors are shown in parentheses. An asterisk by the $\alpha_{3}$ and $\alpha_{M}$ coefficients indicates statistical significance at the $5 \%$ level.

\begin{tabular}{|l|c|c|c|c|c|}
\hline Country & $\alpha_{0}$ & $\alpha_{1}$ & $\alpha_{2}$ & $\alpha_{3}$ & $\alpha_{M}$ \\
\hline \hline Australia & 0.1311 & 0.7463 & 0.191 & $-0.1028^{*}$ & $-0.0443^{*}$ \\
& $(0.016)$ & $(0.022)$ & $(0.009)$ & $(0.015)$ & $(0.013)$ \\
\hline Austria & 0.0969 & 0.7511 & 0.1991 & -0.0041 & $-0.0264^{*}$ \\
& $(0.012)$ & $(0.018)$ & $(0.013)$ & $(0.021)$ & $(0.011)$ \\
\hline Belgium & 0.045 & 0.8577 & 0.0864 & -0.0112 & $-0.0308^{*}$ \\
& $(0.012)$ & $(0.027)$ & $(0.017)$ & $(0.020)$ & $(0.011)$ \\
\hline Canada & 0.0153 & 0.8423 & 0.1405 & $-0.0261^{*}$ & 0.0012 \\
& $(0.002)$ & $(0.007)$ & $(0.008)$ & $(0.009)$ & $(0.004)$ \\
\hline Chile & 0.2407 & 0.7074 & 0.2625 & -0.0337 & $-0.0837^{*}$ \\
& $(0.032)$ & $(0.021)$ & $(0.021)$ & $(0.020)$ & $(0.013)$ \\
\hline Denmark & 0.0512 & 0.9242 & 0.0586 & $-0.0284^{*}$ & $-0.0362^{*}$ \\
& $(0.007)$ & $(0.007)$ & $(0.006)$ & $(0.006)$ & $(0.006)$ \\
\hline Finland & 0.0744 & 0.8446 & 0.0812 & 0.0145 & 0.0112 \\
& $(0.011)$ & $(0.018)$ & $(0.011)$ & $(0.012)$ & $(0.010)$ \\
\hline France & 0.0579 & 0.8856 & 0.0629 & $0.0544^{*}$ & $-0.0272^{*}$ \\
& $(0.014)$ & $(0.016)$ & $(0.012)$ & $(0.018)$ & $(0.009)$ \\
\hline Germany & 0.0307 & 0.8989 & 0.0668 & $0.0253^{*}$ & $-0.0075^{*}$ \\
& $(0.004)$ & $(0.007)$ & $(0.008)$ & $(0.009)$ & $(0.003)$ \\
\hline Hong Kong & 0.087 & 0.8231 & 0.1189 & $0.1142^{*}$ & $-0.0206^{*}$ \\
& $(0.007)$ & $(0.005)$ & $(0.009)$ & $(0.010)$ & $(0.004)$ \\
\hline Hungary & 0.3701 & 0.5299 & 0.3692 & $-0.181^{*}$ & 0.0427 \\
& $(0.032)$ & $(0.028)$ & $(0.024)$ & $(0.029)$ & $(0.023)$ \\
\hline Israel & 0.1748 & 0.7909 & 0.1315 & $0.0617^{*}$ & $-0.0432^{*}$ \\
& $(0.034)$ & $(0.023)$ & $(0.021)$ & $(0.025)$ & $(0.015)$ \\
\hline Italy & 0.0529 & 0.902 & 0.0749 & -0.013 & $-0.0094^{*}$ \\
& $(0.007)$ & $(0.008)$ & $(0.007)$ & $(0.007)$ & $(0.004)$ \\
\hline
\end{tabular}


Table 6: Continued

\section{Effect of Futures Introduction on GJR-GARCH Volatility: Multiplicative Dummy}

Constrained Maximum Likelihood parameter estimates are reported for the GJRGARCH model with a multiplicative dummy:

$$
h_{t}=\left(1+\alpha_{M} D_{t}\right)\left[\alpha_{0}+\alpha_{1} h_{t-1}+\alpha_{2} \varepsilon_{t-1}^{2}+\alpha_{3} \max \left(0,-\varepsilon_{t-1}\right)^{2}\right],
$$

where $\varepsilon_{t}$ is the residual from autoregression 2, and $\alpha_{M}$ is a dummy variable equal to zero before and one after the futures introduction. Standard errors are shown in parentheses. An asterisk by the $\alpha_{3}$ and $\alpha_{M}$ coefficients indicates statistical significance at the $5 \%$ level.

\begin{tabular}{|l|c|c|c|c|c|}
\hline Country & $\alpha_{0}$ & $\alpha_{1}$ & $\alpha_{2}$ & $\alpha_{3}$ & $\alpha_{M}$ \\
\hline \hline Japan & 0.0309 & 0.8725 & 0.0664 & $0.045^{*}$ & $0.0127^{*}$ \\
& $(0.004)$ & $(0.010)$ & $(0.005)$ & $(0.009)$ & $(0.004)$ \\
\hline Korea & 0.1154 & 0.8351 & 0.0799 & $0.09^{*}$ & 0.0149 \\
& $(0.025)$ & $(0.021)$ & $(0.014)$ & $(0.022)$ & $(0.012)$ \\
\hline Malaysia & 0.0817 & 0.8225 & 0.1191 & $0.0437^{*}$ & $-0.0211^{*}$ \\
& $(0.009)$ & $(0.009)$ & $(0.007)$ & $(0.010)$ & $(0.009)$ \\
\hline Netherlands & 0.1216 & 0.8071 & 0.0771 & $0.0931^{*}$ & $-0.0836^{*}$ \\
& $(0.013)$ & $(0.015)$ & $(0.012)$ & $(0.013)$ & $(0.010)$ \\
\hline Norway & 0.0524 & 0.8674 & 0.0975 & 0.012 & $-0.0371^{*}$ \\
& $(0.005)$ & $(0.005)$ & $(0.006)$ & $(0.011)$ & $(0.005)$ \\
\hline Portugal & 0.3137 & 0.2647 & 0.2987 & 0.0129 & -0.0115 \\
& $(0.050)$ & $(0.084)$ & $(0.031)$ & $(0.048)$ & $(0.048)$ \\
\hline South Africa & 0.2772 & 0.7237 & 0.3579 & $-0.217^{*}$ & $-0.1817^{*}$ \\
& $(0.028)$ & $(0.019)$ & $(0.028)$ & $(0.035)$ & $(0.013)$ \\
\hline Spain & 0.0702 & 0.8157 & 0.1448 & $-0.0366^{*}$ & -0.0012 \\
& $(0.010)$ & $(0.016)$ & $(0.013)$ & $(0.015)$ & $(0.007)$ \\
\hline Sweden & 0.0495 & 0.8988 & 0.0499 & $0.0492^{*}$ & -0.0113 \\
& $(0.009)$ & $(0.011)$ & $(0.008)$ & $(0.011)$ & $(0.008)$ \\
\hline Switzerland & 0.2491 & 0.6765 & 0.1098 & 0.039 & $-0.1255^{*}$ \\
& $(0.058)$ & $(0.060)$ & $(0.021)$ & $(0.023)$ & $(0.029)$ \\
\hline United Kingdom & 0.011 & 0.937 & 0.0474 & 0.013 & $-0.0096^{*}$ \\
& $(0.002)$ & $(0.005)$ & $(0.005)$ & $(0.007)$ & $(0.003)$ \\
\hline United States & 0.0046 & 0.9204 & 0.0446 & $0.0309^{*}$ & $0.0133^{*}$ \\
& $(0.001)$ & $(0.005)$ & $(0.005)$ & $(0.005)$ & $(0.002)$ \\
\hline & & & & & \\
& & & & \\
& & & & & \\
& & & & & \\
& & &
\end{tabular}


Table 7:

\section{ARIMA Specifications for Volume and Open Interest}

This table reports the ARIMA models used to decompose futures volume and open interest series into expected and unexpected components. The models were selected using the standard Box-Jenkins approach. The corresponding Ljung-Box test statistics are reported. An asterisk indicates statistical significance at the one percent level, meaning that some significant twelfth-order serial correlation remains in the residuals.

\begin{tabular}{|c|c|c|c|c|}
\hline Country & Volume & LBQ(12) & Open Interest & LBQ(12) \\
\hline Australia & ARIMA(4,1,3) & $34.4^{*}$ & ARIMA $(5,1,5)$ & $57.5^{*}$ \\
\hline Austria & $\operatorname{ARIMA}(2,0,5)$ & 10.8 & $\operatorname{ARIMA}(1,1,5)$ & 12.6 \\
\hline Belgium & $\operatorname{ARIMA}(5,0,0)$ & 8.4 & $\operatorname{ARIMA}(2,1,1)$ & 14.4 \\
\hline Canada & $\operatorname{ARIMA}(5,1,5)$ & 1.3 & ARIMA $(0,1,5)$ & $26.3^{*}$ \\
\hline Denmark & $\operatorname{ARIMA}(2,0,5)$ & 10.5 & $\operatorname{ARIMA}(5,1,0)$ & 6.3 \\
\hline France & $\operatorname{ARIMA}(4,1,4)$ & $48.5^{*}$ & $\operatorname{ARIMA}(1,1,1)$ & 10.8 \\
\hline Germany & $\operatorname{ARIMA}(4,1,2)$ & 9.5 & $\operatorname{ARIMA}(4,1,2)$ & 9.8 \\
\hline Hong Kong & $\operatorname{ARIMA}(2,1,5)$ & $34.8^{*}$ & $\operatorname{ARIMA}(1,1,3)$ & 11.3 \\
\hline Italy & $\operatorname{ARIMA}(4,1,3)$ & $18.8^{*}$ & $\operatorname{ARIMA}(4,1,1)$ & 3.1 \\
\hline Japan & $\operatorname{ARIMA}(5,1,5)$ & $10.9^{*}$ & $\operatorname{ARIMA}(0,1,5)$ & 10.6 \\
\hline Korea & $\operatorname{ARIMA}(4,1,5)$ & $14.0^{*}$ & $\operatorname{ARIMA}(2,1,4)$ & 2.1 \\
\hline Netherlands & $\operatorname{ARIMA}(5,0,1)$ & $35.2^{*}$ & ARIMA $(1,1,5)$ & 3.9 \\
\hline Norway & $\operatorname{ARIMA}(5,0,0)$ & $20.8^{*}$ & ARIMA $(1,1,5)$ & 10.1 \\
\hline Portugal & $\operatorname{ARIMA}(3,1,1)$ & 11.9 & $\operatorname{ARIMA}(3,1,5)$ & 1.3 \\
\hline Spain & $\operatorname{ARIMA}(5,0,0)$ & 17.3 & $\operatorname{ARIMA}(3,1,3)$ & 8.4 \\
\hline Sweden & $\operatorname{ARIMA}(4,0,3)$ & 8.8 & $\operatorname{ARIMA}(2,1,5)$ & 11.2 \\
\hline Switzerland & ARIMA $(5,0,0)$ & 7.7 & $\operatorname{ARIMA}(1,1,5)$ & 10.3 \\
\hline United Kingdom & $\operatorname{ARIMA}(5,0,0)$ & $47.8^{*}$ & ARIMA $(1,1,1)$ & 22.2 \\
\hline United States & $\operatorname{ARIMA}(4,1,1)$ & $102.5^{*}$ & ARIMA $(5,1,5)$ & 5.9 \\
\hline
\end{tabular}


Table 8: Effect of Futures Trading Activity on Volatility

Estimated coefficients from a GJR-GARCH model with expected and unexpected components of futures trading activity variables:

$$
\begin{aligned}
h_{t} & =\alpha_{0}+\alpha_{1} h_{t-1}+\alpha_{2} \varepsilon_{t-1}^{2}+\alpha_{3} \max \left(0,-\varepsilon_{t-1}\right)^{2} \\
& +\alpha_{4} E x p V o l+\alpha_{5} U n \exp V o l+\alpha_{6} E x p O I+\alpha_{7} U n \exp O I
\end{aligned}
$$

For computational reasons, the volume and open interest series are standardized to have a mean between zero and one. Scaling units are reported below the country

\begin{tabular}{|c|c|c|c|c|c|c|c|c|}
\hline $\begin{array}{l}\text { Country } \\
\text { Vol } \mid O I\end{array}$ & $\alpha_{0}$ & $\alpha_{1}$ & $\alpha_{2}$ & $\alpha_{3}$ & $\alpha_{4}$ & $\alpha_{5}$ & $\alpha_{6}$ & $\alpha_{7}$ \\
\hline $\begin{array}{l}\text { Australia } \\
10^{4} \mid 10^{5}\end{array}$ & $\begin{array}{l}0.1342 \\
(0.166)\end{array}$ & $\begin{array}{l}0.7087 \\
(0.026)\end{array}$ & $\begin{array}{l}0.1745 \\
(0.009) \\
\end{array}$ & $\begin{array}{c}-0.0941 \\
(0.016)\end{array}$ & $\begin{array}{l}0.0346 \\
(0.046)\end{array}$ & $\begin{array}{l}0.4671^{*} \\
(0.059)\end{array}$ & $\begin{array}{l}-0.0508 \\
(0.042)\end{array}$ & $\begin{array}{c}-0.06379 \\
(0.163)\end{array}$ \\
\hline $\begin{array}{l}\text { Austria } \\
10^{4} \mid 10^{5}\end{array}$ & $\begin{array}{r}0.2032 \\
(0.027)\end{array}$ & $\begin{array}{c}0.82 \\
(0.033)\end{array}$ & $\begin{array}{l}0.0963 \\
(0.022)\end{array}$ & $\begin{array}{c}-0.01 \\
(0.026)\end{array}$ & $\begin{array}{c}-0.6353^{*} \\
(0.182)\end{array}$ & $\begin{array}{l}2.0146^{*} \\
(0.272)\end{array}$ & $\begin{array}{l}-0.0812 \\
(0.069)\end{array}$ & $\begin{array}{r}-0.7615^{*} \\
(0.204)\end{array}$ \\
\hline $\begin{array}{l}\text { Belgium } \\
10^{4} \mid 10^{4}\end{array}$ & $\begin{array}{l}0.0547 \\
(0.022)\end{array}$ & $\begin{array}{l}0.8425 \\
(0.048)\end{array}$ & $\begin{array}{l}0.0575 \\
(0.019)\end{array}$ & $\begin{array}{l}0.0064 \\
(0.028)\end{array}$ & $\begin{array}{l}-0.0077 \\
(0.124)\end{array}$ & $\begin{array}{c}0.3832 \\
(0.266)\end{array}$ & $\begin{array}{l}-0.0133 \\
(0.014)\end{array}$ & $\begin{array}{l}-0.4163 \\
(0.217)\end{array}$ \\
\hline $\begin{array}{l}\text { Canada } \\
10^{3} \mid 10^{4}\end{array}$ & $\begin{array}{l}0.0263 \\
(0.004)\end{array}$ & $\begin{array}{l}0.8455 \\
(0.015)\end{array}$ & $\begin{array}{l}0.1432 \\
(0.015)\end{array}$ & $\begin{array}{l}-0.0767 \\
(0.014)\end{array}$ & $\begin{array}{l}-0.0093 \\
(0.008)\end{array}$ & $\begin{array}{c}0.0491^{*} \\
(0.015)\end{array}$ & $\begin{array}{c}-0.0009 \\
(0.005)\end{array}$ & $\begin{array}{c}-0.2244^{*} \\
(0.057)\end{array}$ \\
\hline $\begin{array}{l}\text { Denmark } \\
10^{4} \mid 10^{4}\end{array}$ & $\begin{array}{l}0.2727 \\
(0.047)\end{array}$ & $\begin{array}{l}0.3764 \\
(0.064)\end{array}$ & $\begin{array}{l}0.2096 \\
(0.036)\end{array}$ & $\begin{array}{l}-0.0904 \\
(0.044)\end{array}$ & $\begin{array}{l}1.9812^{*} \\
(0.525)\end{array}$ & $\begin{array}{l}3.8229^{*} \\
(0.327)\end{array}$ & $\begin{array}{c}-0.2113^{*} \\
(0.076)\end{array}$ & $\begin{array}{l}-0.3571 \\
(0.829)\end{array}$ \\
\hline $\begin{array}{l}\text { France } \\
10^{5} \mid 10^{6}\end{array}$ & $\begin{array}{c}0.295 \\
(0.053)\end{array}$ & $\begin{array}{l}0.5485 \\
(0.070)\end{array}$ & $\begin{array}{l}0.0781 \\
(0.025)\end{array}$ & $\begin{array}{l}0.0479 \\
(0.035)\end{array}$ & $\begin{array}{l}0.7452 \\
(0.391)\end{array}$ & $\begin{array}{l}3.0331^{*} \\
(0.334)\end{array}$ & $\begin{array}{c}-0.396 \\
(0.289)\end{array}$ & $\begin{array}{l}-2.6735 \\
(2.838)\end{array}$ \\
\hline $\begin{array}{l}\text { Germany } \\
10^{5} \mid 10^{5}\end{array}$ & $\begin{array}{l}0.3404 \\
(0.050)\end{array}$ & $\begin{array}{l}0.4334 \\
(0.072)\end{array}$ & $\begin{array}{c}0.033 \\
(0.029)\end{array}$ & $\begin{array}{l}0.0899 \\
(0.046)\end{array}$ & $\begin{array}{l}1.0981^{*} \\
(0.289)\end{array}$ & $\begin{array}{l}4.2413^{*} \\
(0.364)\end{array}$ & $\begin{array}{c}-0.1279^{*} \\
(0.040)\end{array}$ & $\begin{array}{l}-0.2444 \\
(0.390)\end{array}$ \\
\hline $\begin{array}{l}\text { Hong Kong } \\
10^{5} \mid 10^{5}\end{array}$ & $\begin{array}{l}0.4442 \\
(0.055)\end{array}$ & $\begin{array}{l}0.4131 \\
(0.056)\end{array}$ & $\begin{array}{l}0.1507 \\
(0.033)\end{array}$ & $\begin{array}{c}0.131 \\
(0.049)\end{array}$ & $\begin{array}{l}2.6692^{*} \\
(1.202)\end{array}$ & $\begin{array}{c}11.2339^{*} \\
(0.817)\end{array}$ & $\begin{array}{c}-0.539 \\
(0.449)\end{array}$ & $\begin{array}{r}-5.5596^{*} \\
(1.484)\end{array}$ \\
\hline $\begin{array}{l}\text { Italy } \\
10^{5} \mid 10^{5}\end{array}$ & $\begin{array}{l}0.5237 \\
(0.151)\end{array}$ & $\begin{array}{l}0.3059 \\
(0.130)\end{array}$ & $\begin{array}{l}0.2601 \\
(0.081)\end{array}$ & $\begin{array}{l}-0.1106 \\
(0.099)\end{array}$ & $\begin{array}{l}1.8269 \\
(1.542)\end{array}$ & $\begin{array}{l}8.5268^{*} \\
(1.126)\end{array}$ & $\begin{array}{l}-0.631 \\
(0.969)\end{array}$ & $\begin{array}{l}-5.899^{*} \\
(2.053)\end{array}$ \\
\hline $\begin{array}{l}\text { Japan } \\
10^{4} \mid 10^{6}\end{array}$ & $\begin{array}{l}0.0121 \\
(0.003)\end{array}$ & $\begin{array}{l}0.9111 \\
(0.010)\end{array}$ & $\begin{array}{l}0.0217 \\
(0.007)\end{array}$ & $\begin{array}{l}0.0979 \\
(0.013)\end{array}$ & $\begin{array}{c}-0.003 \\
(0.010)\end{array}$ & $\begin{array}{c}0.4131^{*} \\
(0.098)\end{array}$ & $\begin{array}{c}0.0757^{*} \\
(0.025)\end{array}$ & $\begin{array}{l}-0.4698 \\
(1.201)\end{array}$ \\
\hline $\begin{array}{l}\text { Netherlands } \\
10^{4} \mid 10^{5}\end{array}$ & $\begin{array}{l}0.0488 \\
(0.010)\end{array}$ & $\begin{array}{l}0.9156 \\
(0.016)\end{array}$ & $\begin{array}{l}0.0474 \\
(0.013)\end{array}$ & $\begin{array}{l}0.0022 \\
(0.013)\end{array}$ & $\begin{array}{l}-0.0122 \\
(0.026)\end{array}$ & $\begin{array}{l}0.2918^{*} \\
(0.077)\end{array}$ & $\begin{array}{c}-0.0972^{*} \\
(0.044)\end{array}$ & $\begin{array}{r}-0.7806^{*} \\
(0.388)\end{array}$ \\
\hline $\begin{array}{l}\text { Norway } \\
10^{3} \mid 10^{4}\end{array}$ & $\begin{array}{l}0.0403 \\
(0.010)\end{array}$ & $\begin{array}{l}0.8644 \\
(0.019)\end{array}$ & $\begin{array}{l}0.0965 \\
(0.015)\end{array}$ & $\begin{array}{l}-0.0026 \\
(0.025)\end{array}$ & $\begin{array}{c}0.065 \\
(0.062)\end{array}$ & $\begin{array}{c}0.1827^{*} \\
(0.085)\end{array}$ & $\begin{array}{c}-0.1504^{*} \\
(0.068)\end{array}$ & $\begin{array}{l}-0.5672 \\
(0.515)\end{array}$ \\
\hline $\begin{array}{l}\text { Spain } \\
10^{5} \mid 10^{5}\end{array}$ & $\begin{array}{l}0.2958 \\
(0.051)\end{array}$ & $\begin{array}{l}0.6943 \\
(0.071)\end{array}$ & $\begin{array}{l}0.0484 \\
(0.025)\end{array}$ & $\begin{array}{l}0.0993 \\
(0.037)\end{array}$ & $\begin{array}{l}0.3125 \\
(0.506)\end{array}$ & $\begin{array}{l}4.8436^{*} \\
(0.502)\end{array}$ & $\begin{array}{c}-0.3706^{*} \\
(0.160)\end{array}$ & $\begin{array}{l}-0.9556 \\
(0.764)\end{array}$ \\
\hline $\begin{array}{l}\text { Sweden } \\
10^{4} \mid 10^{5}\end{array}$ & $\begin{array}{l}0.0009 \\
(0.072)\end{array}$ & $\begin{array}{l}0.8883 \\
(0.059)\end{array}$ & $\begin{array}{l}0.0032 \\
(0.027)\end{array}$ & $\begin{array}{l}0.0535 \\
(0.038)\end{array}$ & $\begin{array}{l}0.1223 \\
(0.140)\end{array}$ & $\begin{array}{l}0.2158 \\
(0.167)\end{array}$ & $\begin{array}{c}-0.0172 \\
(0.127)\end{array}$ & $\begin{array}{l}-0.1134 \\
(0.366)\end{array}$ \\
\hline $\begin{array}{l}\text { Switzerland } \\
10^{4} \mid 10^{5}\end{array}$ & $\begin{array}{l}0.2207 \\
(0.036)\end{array}$ & $\begin{array}{l}0.7317 \\
(0.082)\end{array}$ & $\begin{array}{l}0.0357 \\
(0.021)\end{array}$ & $\begin{array}{l}0.0523 \\
(0.030)\end{array}$ & $\begin{array}{l}-0.0024 \\
(0.097)\end{array}$ & $\begin{array}{l}0.8582^{*} \\
(0.085)\end{array}$ & $\begin{array}{c}-0.4029^{*} \\
(0.175)\end{array}$ & $\begin{array}{c}-2.3471^{*} \\
(1.132)\end{array}$ \\
\hline $\begin{array}{l}\text { United Kingdom } \\
10^{4} \mid 10^{5}\end{array}$ & $\begin{array}{l}0.0393 \\
(0.007)\end{array}$ & $\begin{array}{l}0.9036 \\
(0.016)\end{array}$ & $\begin{array}{c}0.045 \\
(0.010)\end{array}$ & $\begin{array}{l}0.0164 \\
(0.011)\end{array}$ & $\begin{array}{l}-0.0103^{*} \\
(0.005)\end{array}$ & $\begin{array}{l}0.1071^{*} \\
(0.018)\end{array}$ & $\begin{array}{l}-0.0081 \\
(0.005)\end{array}$ & $\begin{array}{c}-0.3577^{*} \\
(0.115)\end{array}$ \\
\hline $\begin{array}{l}\text { United States } \\
10^{5} \mid 10^{6}\end{array}$ & $\begin{array}{l}0.0052 \\
(0.002)\end{array}$ & $\begin{array}{l}0.9193 \\
(0.005)\end{array}$ & $\begin{array}{l}0.0554 \\
(0.007)\end{array}$ & $\begin{array}{l}0.0231 \\
(0.007)\end{array}$ & $\begin{array}{l}0.0007 \\
(0.003)\end{array}$ & $\begin{array}{l}0.2241^{*} \\
(0.017)\end{array}$ & $\begin{array}{l}0.0083 \\
(0.005)\end{array}$ & $\begin{array}{r}-0.7909^{*} \\
(0.168)\end{array}$ \\
\hline
\end{tabular}
name. 
Table 9:

\section{Joint Dynamics of Country and World Returns}

Constrained Maximum Likelihood parameter estimates and standard errors are reported for the BEKK model with dummy variables for futures listing in each country's conditional variance equation and conditional covariance equation:

$$
\begin{aligned}
{\left[\begin{array}{ll}
h_{11, t} & h_{12, t} \\
h_{12, t} & h_{22, t}
\end{array}\right] } & =\mathbf{C}^{\prime} \mathbf{C}+\left[\begin{array}{ll}
a_{11} & a_{12} \\
a_{21} & a_{22}
\end{array}\right]^{\prime}\left[\begin{array}{cc}
\varepsilon_{1, t-1}^{2} & \varepsilon_{1, t-1} \varepsilon_{2, t-1} \\
\epsilon_{2, t-1} \varepsilon_{1, t-1} & \varepsilon_{2, t-1}^{2}
\end{array}\right]\left[\begin{array}{ll}
a_{11} & a_{12} \\
a_{21} & a_{22}
\end{array}\right] \\
& +\left[\begin{array}{ll}
g_{11} & g_{12} \\
g_{12} & g_{22}
\end{array}\right]^{\prime}\left[\begin{array}{ll}
h_{11, t-1} & h_{12, t-1} \\
h_{12, t-1} & h_{22, t-1}
\end{array}\right]\left[\begin{array}{ll}
g_{11} & g_{12} \\
g_{12} & g_{22}
\end{array}\right]+\left[\begin{array}{cc}
d_{11} & d_{12} \\
d_{12} & 0
\end{array}\right] D_{t}
\end{aligned}
$$

For brevity, coefficients specific to the world conditional variance equation are not reported. An asterisk by the $d_{11}$ and $d_{12}$ coefficients indicates statistical significance

\begin{tabular}{|c|c|c|c|c|c|c|c|c|c|}
\hline Country & $c_{11}$ & $c_{12}$ & $a_{11}$ & $a_{12}$ & $a_{21}$ & $g_{11}$ & $g_{12}$ & $d_{11}$ & $d_{12}$ \\
\hline Australia & & & $\begin{array}{c}0.0101 \\
(0.0083)\end{array}$ & $\begin{array}{c}-0.0132 \\
(0.0077) \\
\end{array}$ & & & $\begin{array}{c}0.1461 \\
(0.0543)\end{array}$ & $\begin{array}{l}-0.0937^{*} \\
(0.0194)\end{array}$ & $\begin{array}{c}0.0009 \\
(0.0179)\end{array}$ \\
\hline Austria & $\begin{array}{c}0.0041 \\
(0.0013)\end{array}$ & $\begin{array}{c}0.0014 \\
(0.0017)\end{array}$ & $\begin{array}{c}0.2367 \\
(0.0060)\end{array}$ & $\begin{array}{c}0.0113 \\
(0.0045)\end{array}$ & & $\begin{array}{c}0.9446 \\
(0.0026)\end{array}$ & $\begin{array}{c}0.9140 \\
(0.0061)\end{array}$ & $\begin{array}{c}0.0017 \\
(0.0015)\end{array}$ & $\begin{array}{c}0.0010 \\
(0.0014)\end{array}$ \\
\hline Belgium & $\begin{array}{c}0.0574 \\
(0.0079) \\
\end{array}$ & & & & & & & $\begin{array}{c}0.0025 \\
(0.0058)\end{array}$ & $\begin{array}{l}0.0132^{*} \\
(0.0046)\end{array}$ \\
\hline Canada & & $\begin{array}{c}0.0162 \\
(0.0015) \\
\end{array}$ & $\begin{array}{c}0.347 \\
(0.0067)\end{array}$ & & & & & $\begin{array}{l}-0.004^{*} \\
(0.0014)\end{array}$ & $\begin{array}{l}-0.0052^{*} \\
(0.0010)\end{array}$ \\
\hline Chile & $\begin{array}{c}0.1718 \\
(0.0205)\end{array}$ & & & & & & & & $\begin{array}{l}0.0688^{*} \\
(0.0290)\end{array}$ \\
\hline Denmark & $\begin{array}{c}0.4576 \\
(0.0334) \\
\end{array}$ & & $\begin{array}{c}0.324 \\
(0.0157)\end{array}$ & & & $\begin{array}{l}79 \\
79)\end{array}$ & & $\begin{array}{l}-0.2076^{*} \\
(0.0153)\end{array}$ & $\begin{array}{l}0.0618^{*} \\
(0.0115)\end{array}$ \\
\hline Finland & $\begin{array}{c}0.0305 \\
(0.0051)\end{array}$ & & $\begin{array}{c}0.403 \\
(0.0140)\end{array}$ & & & $\begin{array}{r}0.7 \\
(0.0\end{array}$ & & $\begin{array}{c}0.0283^{*} \\
(0.0046)\end{array}$ & $\begin{array}{c}0.0089 \\
(0.0084)\end{array}$ \\
\hline France & $\begin{array}{c}0.093 \\
(0.0233) \\
\end{array}$ & & $\begin{array}{c}0.2979 \\
(0.0173) \\
\end{array}$ & & & $\begin{array}{r}0.8 \\
(0.0 \\
\end{array}$ & & $\begin{array}{l}-0.0247 \\
(0.0177)\end{array}$ & $\begin{array}{l}0.0246^{*} \\
(0.0080)\end{array}$ \\
\hline Germany & $\begin{array}{r}0.03 \\
(0.00\end{array}$ & $\begin{array}{r}0.0 \\
(0.0 \\
\end{array}$ & $\begin{array}{c}0.3297 \\
(0.0102) \\
\end{array}$ & $\begin{array}{r}0.0 \\
(0.0 \\
\end{array}$ & & $\begin{array}{r}0.8 \\
(0.0\end{array}$ & & $\begin{array}{c}0.0198^{*} \\
(0.0030) \\
\end{array}$ & $\begin{array}{l}0.0298^{*} \\
(0.0043) \\
\end{array}$ \\
\hline Hong Kong & & $\begin{array}{c}0.0021 \\
(0.0031)\end{array}$ & $\begin{array}{c}0.4153 \\
(0.0082)\end{array}$ & $\begin{array}{r}0.0 \\
(0.0\end{array}$ & & $\begin{array}{c}0.8149 \\
(0.0050)\end{array}$ & & $\begin{array}{c}-0.0046 \\
(0.0071)\end{array}$ & $\begin{array}{l}0.0201^{*} \\
(0.0040)\end{array}$ \\
\hline Hungary & $\begin{array}{c}0.165 \\
(0.0161)\end{array}$ & & $\begin{array}{c}0.5453 \\
(0.0193)\end{array}$ & $\begin{array}{c}0.0109 \\
(0.0029)\end{array}$ & & $\begin{array}{c}0.5829 \\
(0.0183)\end{array}$ & & $\begin{array}{c}0.0553^{*} \\
(0.0234)\end{array}$ & $\begin{array}{l}0.0181^{*} \\
(0.0059)\end{array}$ \\
\hline Israel & & & $\begin{array}{c}0.3963 \\
(0.0231) \\
\end{array}$ & & & $\begin{array}{c}0.8059 \\
(0.0222) \\
\end{array}$ & $\begin{array}{c}0.013 \\
(0.3260)\end{array}$ & $\begin{array}{c}-0.0207 \\
(0.0228) \\
\end{array}$ & $\begin{array}{c}0.0387 \\
(0.0362)\end{array}$ \\
\hline Italy & $\begin{array}{c}0.0486 \\
(0.0043) \\
\end{array}$ & $\begin{array}{c}0.0058 \\
(0.0015) \\
\end{array}$ & $\begin{array}{c}0.2558 \\
(0.0080) \\
\end{array}$ & $\begin{array}{c}-0.0024 \\
(0.0030) \\
\end{array}$ & $\begin{array}{c}0.0127 \\
(0.0100) \\
\end{array}$ & $\begin{array}{c}0.9021 \\
(0.0060)\end{array}$ & $\begin{array}{c}0.8668 \\
(0.0116) \\
\end{array}$ & $\begin{array}{c}0.0023 \\
(0.0055) \\
\end{array}$ & $\begin{array}{l}0.0058^{*} \\
(0.0029) \\
\end{array}$ \\
\hline
\end{tabular}
at the $5 \%$ level. 
Table 9: Continued

\section{Joint Dynamics of Country and World Returns}

Constrained Maximum Likelihood parameter estimates and standard errors are reported for the BEKK model with dummy variables for futures listing in each country's conditional variance equation and conditional covariance equation:

$$
\begin{aligned}
{\left[\begin{array}{ll}
h_{11, t} & h_{12, t} \\
h_{12, t} & h_{22, t}
\end{array}\right] } & =\mathbf{C}^{\prime} \mathbf{C}+\left[\begin{array}{ll}
a_{11} & a_{12} \\
a_{21} & a_{22}
\end{array}\right]^{\prime}\left[\begin{array}{cc}
\varepsilon_{1, t-1}^{2} & \varepsilon_{1, t-1} \varepsilon_{2, t-1} \\
\varepsilon_{2, t-1} \varepsilon_{1, t-1} & \varepsilon_{2, t-1}^{2}
\end{array}\right]\left[\begin{array}{ll}
a_{11} & a_{12} \\
a_{21} & a_{22}
\end{array}\right] \\
& +\left[\begin{array}{ll}
g_{11} & g_{12} \\
g_{12} & g_{22}
\end{array}\right]^{\prime}\left[\begin{array}{ll}
h_{11, t-1} & h_{12, t-1} \\
h_{12, t-1} & h_{22, t-1}
\end{array}\right]\left[\begin{array}{ll}
g_{11} & g_{12} \\
g_{12} & g_{22}
\end{array}\right]+\left[\begin{array}{cc}
d_{11} & d_{12} \\
d_{12} & 0
\end{array}\right] D_{t}
\end{aligned}
$$

For brevity, coefficients specific to the world conditional variance equation are not reported. An asterisk by the $d_{11}$ and $d_{12}$ coefficients indicates statistical significance

\begin{tabular}{|c|c|c|c|c|c|c|c|c|c|}
\hline Country & $c_{11}$ & $c_{12}$ & $a_{11}$ & $a_{12}$ & $a_{21}$ & $g_{11}$ & $g_{12}$ & $d_{11}$ & $d_{12}$ \\
\hline Japan & $\begin{array}{c}0.0181 \\
(0.0022)\end{array}$ & $\begin{array}{c}-0.0047 \\
(0.0011)\end{array}$ & $\begin{array}{c}0.3014 \\
(0.0096)\end{array}$ & $\begin{array}{c}0.0052 \\
(0.0029)\end{array}$ & $\begin{array}{c}0.1747 \\
(0.0069)\end{array}$ & $\begin{array}{c}0.8525 \\
(0.0063)\end{array}$ & $\begin{array}{c}0.8792 \\
(0.0047)\end{array}$ & $\begin{array}{l}0.0317^{*} \\
(0.0035)\end{array}$ & $\begin{array}{l}0.0145^{*} \\
(0.0012)\end{array}$ \\
\hline Korea & $\begin{array}{c}0.1169 \\
(0.0193)\end{array}$ & $\begin{array}{c}0.0567 \\
(0.0200)\end{array}$ & $\begin{array}{c}0.3488 \\
(0.0186)\end{array}$ & $\begin{array}{c}-0.0603 \\
(0.0050)\end{array}$ & $\begin{array}{c}0.1249 \\
(0.0416)\end{array}$ & $\begin{array}{c}0.8262 \\
(0.0163)\end{array}$ & $\begin{array}{l}-0.0284 \\
(0.1988) \\
\end{array}$ & $\begin{array}{c}0.0482 \\
(0.0307)\end{array}$ & $\begin{array}{c}-0.0062 \\
(0.0437) \\
\end{array}$ \\
\hline Malaysia & $\begin{array}{c}0.1102 \\
(0.0071)\end{array}$ & $\begin{array}{c}0.0112 \\
(0.0045)\end{array}$ & $\begin{array}{c}0.3904 \\
(0.0108)\end{array}$ & $\begin{array}{c}0.0191 \\
(0.0041)\end{array}$ & $\begin{array}{c}0.0989 \\
(0.0122)\end{array}$ & $\begin{array}{c}0.7853 \\
(0.0104)\end{array}$ & $\begin{array}{c}0.6658 \\
(0.0284)\end{array}$ & $\begin{array}{l}-0.0388^{*} \\
(0.0075)\end{array}$ & $\begin{array}{c}0.0135 \\
(0.0075)\end{array}$ \\
\hline Netherlands & $\begin{array}{c}0.0944 \\
(0.0081)\end{array}$ & $\begin{array}{c}0.0018 \\
(0.0035)\end{array}$ & $\begin{array}{c}0.2619 \\
(0.0094)\end{array}$ & $\begin{array}{c}0.0262 \\
(0.0050)\end{array}$ & $\begin{array}{c}0.0977 \\
(0.0139)\end{array}$ & $\begin{array}{c}0.8674 \\
(0.0077)\end{array}$ & $\begin{array}{c}0.8139 \\
(0.0097) \\
\end{array}$ & $\begin{array}{c}-0.0538^{*} \\
(0.0053) \\
\end{array}$ & $\begin{array}{l}0.0066^{*} \\
(0.0029)\end{array}$ \\
\hline Norway & $\begin{array}{c}0.1132 \\
(0.0077)\end{array}$ & $\begin{array}{c}0.0473 \\
(0.0027)\end{array}$ & $\begin{array}{c}0.4149 \\
(0.0115)\end{array}$ & $\begin{array}{c}0.0112 \\
(0.0074)\end{array}$ & $\begin{array}{c}0.1566 \\
(0.0095)\end{array}$ & $\begin{array}{c}0.7381 \\
(0.0115)\end{array}$ & $\begin{array}{c}0.3568 \\
(0.0366)\end{array}$ & $\begin{array}{l}-0.0486^{*} \\
(0.0060)\end{array}$ & $\begin{array}{c}0.0125 \\
(0.0084)\end{array}$ \\
\hline Portugal & $\begin{array}{c}0.0247 \\
(0.0043)\end{array}$ & $\begin{array}{l}-0.0040 \\
(0.0061)\end{array}$ & $\begin{array}{c}0.4738 \\
(0.0190)\end{array}$ & $\begin{array}{c}0.0531 \\
(0.0162)\end{array}$ & $\begin{array}{c}0.1618 \\
(0.0233)\end{array}$ & $\begin{array}{c}0.7403 \\
(0.0161)\end{array}$ & $\begin{array}{c}0.3218 \\
(0.1013)\end{array}$ & $\begin{array}{c}-0.0033 \\
(0.0059)\end{array}$ & $\begin{array}{l}0.0425^{*} \\
(0.0135)\end{array}$ \\
\hline South Africa & $\begin{array}{c}0.9573 \\
(0.0946)\end{array}$ & $\begin{array}{c}0.1467 \\
(0.0212)\end{array}$ & $\begin{array}{c}0.3228 \\
(0.0204)\end{array}$ & $\begin{array}{c}-0.0585 \\
(0.0019)\end{array}$ & $\begin{array}{c}0.2147 \\
(0.0212)\end{array}$ & $\begin{array}{c}0.6498 \\
(0.0306)\end{array}$ & $\begin{array}{c}0.8169 \\
(0.0262)\end{array}$ & $\begin{array}{l}-0.8027^{*} \\
(0.0786)\end{array}$ & $\begin{array}{l}-0.1239^{*} \\
(0.0176)\end{array}$ \\
\hline Spain & $\begin{array}{c}0.0407 \\
(0.0045)\end{array}$ & $\begin{array}{c}0.0073 \\
(0.0024)\end{array}$ & $\begin{array}{c}0.3049 \\
(0.0129)\end{array}$ & $\begin{array}{c}0.0164 \\
(0.0065)\end{array}$ & $\begin{array}{c}-0.0292 \\
(0.0060)\end{array}$ & $\begin{array}{c}0.8744 \\
(0.0109)\end{array}$ & $\begin{array}{c}0.8396 \\
(0.0111)\end{array}$ & $\begin{array}{c}0.0089^{*} \\
(0.0037)\end{array}$ & $\begin{array}{c}0.0042 \\
(0.0028)\end{array}$ \\
\hline Sweden & $\begin{array}{c}0.0953 \\
(0.0177)\end{array}$ & $\begin{array}{l}-0.0174 \\
(0.0095)\end{array}$ & $\begin{array}{c}0.2828 \\
(0.0137)\end{array}$ & $\begin{array}{c}0.018 \\
(0.0068)\end{array}$ & $\begin{array}{c}0.0874 \\
(0.0176)\end{array}$ & $\begin{array}{c}0.8629 \\
(0.0113)\end{array}$ & $\begin{array}{c}0.7726 \\
(0.0127)\end{array}$ & $\begin{array}{c}-0.03^{*} \\
(0.0145)\end{array}$ & $\begin{array}{c}0.0314^{*} \\
(0.0098)\end{array}$ \\
\hline Switzerland & $\begin{array}{c}0.2279 \\
(0.0240)\end{array}$ & $\begin{array}{c}-0.01 \\
0.0090\end{array}$ & $\begin{array}{c}0.2863 \\
(0.0229)\end{array}$ & $\begin{array}{c}0.02 \\
(0.0105)\end{array}$ & $\begin{array}{c}0.3394 \\
(0.0176)\end{array}$ & $\begin{array}{c}0.652 \\
(0.0288)\end{array}$ & $\begin{array}{c}0.6596 \\
(0.0172)\end{array}$ & $\begin{array}{c}-0.0667^{*} \\
(0.0117)\end{array}$ & $\begin{array}{c}0.0239^{*} \\
(0.0093)\end{array}$ \\
\hline UK & $\begin{array}{c}0.0279 \\
(0.0040)\end{array}$ & $\begin{array}{c}0.0056 \\
(0.0019)\end{array}$ & $\begin{array}{c}0.2607 \\
(0.0093)\end{array}$ & $\begin{array}{c}0.0073 \\
(0.0050)\end{array}$ & $\begin{array}{c}0.0678 \\
(0.0071)\end{array}$ & $\begin{array}{c}0.8986 \\
(0.0057)\end{array}$ & $\begin{array}{c}0.863 \\
(0.0075)\end{array}$ & $\begin{array}{l}-0.0129^{*} \\
(0.0030)\end{array}$ & $\begin{array}{c}0.001 \\
(0.0016)\end{array}$ \\
\hline US & $\begin{array}{c}0.0106 \\
(0.0013)\end{array}$ & $\begin{array}{c}0.0061 \\
(0.0007)\end{array}$ & $\begin{array}{c}0.2203 \\
(0.0035) \\
\end{array}$ & $\begin{array}{c}-0.0194 \\
(0.0026)\end{array}$ & $\begin{array}{c}0.0074 \\
(0.0062)\end{array}$ & $\begin{array}{c}0.938 \\
(0.0025)\end{array}$ & $\begin{array}{c}0.9419 \\
(0.0021)\end{array}$ & $\begin{array}{c}0.0005 \\
(0.0009)\end{array}$ & $\begin{array}{l}-0.0006 \\
(0.0004)\end{array}$ \\
\hline
\end{tabular}
at the $5 \%$ level. 
No. 93-101 Gordon M. Phillips, and Robert J. Weiner

"Information and Normal Backwardation as Determinants of Trading Performance: Evidence from the North-Sea Oil Forward Market." 1994. The Economic Journal.

No. 93-102 Stephen R. Goldberg and Frank L. Heflin

"The Association Between the Level of International Diversification and Risk."

No. 93-103 John A. Carlson

"Risk Aversion, Foreign Exchange Speculation and Gambler's Ruin."

No. 93-104 John A. Carlson, Aasim M. Husain, and Jeffrey A. Zimmerman

"Penalties and Exclusion in the Rescheduling and Forgiveness of International Loans."

No. 93-105 Kent D. Miller

"Industry and Country Effects on Manager's Perceptions of Environmental Uncertainties." 1993. Journal of International Business Studies, 24: 693-714.

No. 93-106 Stephen R. Goldberg and Joseph H. Godwin

"Foreign Currency Translation Under Two Cases-Integrated and Isolated Economies."

No. 93-107 Kent D. Miller

"A Comparison of Managers' Uncertainty Perceptions and Country Risk Indices."

No. 93-108 Jon D. Haveman

"The Effect of Trade Induced Displacement on Unemployment and Wages."

No. 93-109 Jon D. Haveman

"Some Welfare Effects of Dynamic Customs Union Formation."

No. 93-110 John A. Carlson and Insook Kim

"Central Banks' Expected Profits From Intervention."

No. 94-001 Casper G. De Vries, Phillip A. Stork, and Kees G. Koedijk

"Between Realignments and Intervention: The Belgian Franc in the European Monetary System."

No. 94-002 Casper G. de Vries and K. U. Leuven

"Stylized Facts of Nominal Exchange Rate Returns."

No. 94-003 Kent D. Miller

"Operational Flexibility Responses to Environmental Uncertainties."

No. 94-004 Kent D. Miller

"Economic Exposure and Integrated Risk Management."

No. 94-005 Kent D. Miller

"Diversification Responses to Environmental Uncertainties."

No. 94-006 John M. Hannon, Ing-Chung Huang, and Bih-Shiaw Jaw

"International Human Resource Strategy and Its Determinants: The Case of Multinationals and Their Subsidiaries in Taiwan." 
No. 94-007 John M. Hannon, Ing-Chung Huang, and Bih-Shiaw Jaw

"International Human Resource Strategy and Control: The Case of Multinationals and Their

Subsidiaries."

No. 94-008 · John M. Hannon and Yoko Sano

"Customer-Driven Human Resource Policies and Practices in Japan."

No. 94-009 John A. Carlson and Insook Kim

"Leaning Against the Wind: Do Central Banks Necessarily Lose?"

No. 94-010 John A. Carlson and David W. Schodt

"Beyond the Lecture: Case Teaching and the Learning of Economic Theory."

No. 94-011 Alok R. Chaturvedi, Hemant K. Jain, and Derek L. Nazareth

"Key Information Systems Management Issues in Developing Countries: Differences in the Indian and US Contexts."

No. 94-012 Jon Haveman,

"The Influence of Changing Trade Patterns on Displacements of Labor."

No. 94-013 Stephen Goldberg, Charles A. Tritschler, and Joseph H. Godwin

"Financial Reporting for Foreign Exchange Derivatives."

No. 94-014 Charles Noussair, Charles Plott, and Raymond Riezman

"Una investigacion experimental sobre la estructura del comercia interncional (Spanish Version)."

Translated: "An Experimental Investigation About the Structure of International Commerce."

No. 94-015 Marie Thursby and Richard Jensen

"Patent Races, Product Standards, and International Competition."

No. 94-016 Kent D. Miller and Jeffrey J. Reuer

"Firm Strategy and Economic Exposure to Foreign Exchange Rate Movements."

No. 94-017 John Hannon and Yoko Sano

"The Determinants of Corporate Attractiveness in Japan."

No. 94-018 John Hannon, Ing-Chung Huang, and Cheng-Chen Lin

"The Mediating Effect of Pre/Post Assignment Acitivities on the Quality of Work Life of Expatriates:

Evidence for Managers in the P.R.C."

No. 94-019 John Hannon, Ing-Chung Huang, and Cheng-Chen Lin

"The Mediating Effects of Organization Commitment and Job Involvement on the Relationship Between Quality of Work Life and Customer Service Attitudes."

No. 94-020 John A. Carlson and Marc Surchat

"A Model for Filter-Rule Gains in Foreign Exchange Markets."

No. 94-021 Ch.N. Noussair, Ch.R. Plott, and R. Riezman

"The Principles of Exchange Rate Determination in an International Finance Experiment."

No. 94-022 Stephen R. Goldberg, Joseph H. Godwin, Myung-Sun Kim, and Charles A. Tritschler

"On The Determinants of Corporate Hedging With Financial Derivatives."

No. 95-001 Timothy B. Folta

"Sovereignty Conditions and Governance Modes: An Option Theory Approach."

No. 95-002 John A. Carlson and Dong-Geun Han

"Monetary Coordination, Fixed Exchange Rates and Noisy Markets." 
No. 95-004

No. 95-005

No. 95-006

No. 95-007

No. 96-001

No. 96-002

No. 96-003

No. 96-004

No. 96-005

No. 96-006

No. 96-007

No. 96-008

No. 96-009

No. 96-010

No. 96-011

No. 96-012

No. 96-013
Kent D. Miller and Jeffrey J. Reuer

“Asymmetric Corporate Exposures to Foreign Exchange Rates."

Gerald J. Lynch and Bradley T. Ewing

"Money Growth Variability and the Term Structure of Interest Rates in Japan."

Nicholas C. Petruzzi and Maqbool Dada

"Inventory and Pricing in Global Operations: Learning from Observed Demand."

Kala Krishna and Marie Thursby

“Whither Flat Panel Displays?"

Thomas Brush, Catherine Maritan, and Aneel Karnani

"Managing a Network of Plants Within Multinational Firms."

John J. McConnell, Heidi J. Dybevik, David Haushalter, and Erik Lie

"A Survey on Domestic and International Stock Exchange Listings with Implications for Markets and Managers."

Kala Krishna, Suddhasatwa Roy, and Marie Thursby

"Implementing Market Access."

Jon Haveman, David Hammels

"Trade Creation and Trade Diversion: New Empirical Results."

Riki Takeuchi, John M. Hannon

"Antecedents of Expatriate Spouse Adjustments: An Analysis of Japanese Spouses in the United States."

Bih-Shiaw Jaw, John M. Hannon

"Determinants of International and Intercultural Human Resource Control: The Case Of Taiwanese Subsidiaries in the People's Republic of China."

John M. Hannon, Riki Takeuchi

"Adjustment and Job Satisfaction as Antecedents of Intent to Stay: The Case of Japanese Expatriates in the United States."

John M. Hannon

"Using International Human Resource Management to Inform the Business Intelligence Function."

Jeffrey J. Reuer, Kent D. Miller

"Agency Costs and the Performance Implications of International Joint Venture Internalization."

Neven Valev

"International Lending by U.S. Banks."

Kala Krishna, Marie Thursby, and Suddhasatwa Roy

"Implementing Market Access." (revised)

Jon D. Haveman

"The Effect of Trade Induced Displacement on Unemployment and Wages."

Robert A. Buckle and John A. Carlson

"Inflation and Asymmetric Price Adjustment." 
No. 97-001

No. 97-002

No. 97-003

No. 97-004

No. 97-005

No. 97-006

No. 97-007

No. 97-008

No. 97-009

No. 98-001

No. 98-002

No. 98-003

No. 98-004

No. 98-005

No. 98-006

No. 98-007

No. 98-008

No. 99-001
Jeffrey J. Reuer

"Shareholder Wealth Effects of Joint Venture Termination: A Transaction Cost Analysis."

Jon Haveman and David Hummels

"What Can We Learn from Bilateral Trade? Gravity and Beyond."

Douglas Bowman, John U. Farley, and David C. Schmittlein

"Cross-National Empirical Generalization of a Supplier Selection and Usage Model for Foreign

Exchange Services."

Kent D. Miller

"Measurement of Perceived Environmental Uncertainties: Response and Extension."

John A. Carlson, C. O. Osler

"Rational Speculators and Exchange Rate Volatility."

Marie Thursby, Kala Krishna, and Suddhasatwa Roy

"Procompetitive Market Access," Forthcoming, Business and Economics for the $21^{\text {st }}$ Century, Vol. 1.

John A. Carlson

"Currency Boards, Expectations and Inflation Persistence."

Jon Haveman, Usha C. Nair, and Jerry G. Thursby

"The Effects of Protection on the Pattern of Trade: A Disaggregated Analysis," Forthcoming, Business and Economics for the $21^{\text {st }}$ Century, Vol. 1.

George Horwich

"Economic Lessons of the Kobe Earthquake."

John J. McConnell, Kenneth A. Carow, and Gayle R. Erwin

"Financing Publicly Traded U.S. Corporations in Public and Private Security Markets, 1970-1997:

Where, How, How Much, With What, When, and Why."

Timothy N. Cason, Tatsuyoshi Saijo, and Takehiko Yamato

"Voluntary Participation and Spite in Public Good Provision Experiments: An International Comparison."

Jon D. Haveman, Janet S. Netz, and Vivian Lei

"International Integration and Growth: A Survey and Empirical Investigation."

Keith V. Smith, Nabil T. Khoury, and Peter I. MacKay

"Comparing Working Capital Practices in Canada, the United States, and Australia: A Note."

John A. Carison and Neven T. Valev

"Expectations Formation and Inflation Persistence."

John A. Carlson and Carol L. Osler

"Determinants of Currency Risk Premiums."

Jon D. Haveman, Usha Nair-Reichert, and Jerry Thursby

"Trade Reduction, Diversion and Compression: Empirical Regularities in the Effect of Protective Measures."

Kale Krishna, Suddhasatwa Roy, and Marie Thursby

"Can Subsidies for MARs be Procompetitive?"

Gabriele Camera and Johannes Winkler

"Stores, Prices and Currency Substitution" 
No. 99-002 John A. Carlson and Neven T. Valev

"Sources of Dispersion in Inflation Forecasts"

No. 99-003 Timothy N. Cason, Tatsuyoshi Saijo and Takehiko Yamato

"Voluntary Participation and Spite in Public Good Provision Experiments: An International Comparison"

No. 99-004 Jay Dahya, John J. McConnell and Nickolaos G. Travlos

"The Cadbury Committee, Corporate Performance and Top Management Turnover"

No. 99-005 David J. Denis, Diane K. Denis and Keven Yost

"Global Diversification, Industrial Diversification and Firm Value"

No. 99-006 Timothy B. Folta and Walter J. Ferrier

"The Effect of National Culture on Partner Buyouts in Cross-Border Biotechnology Alliances"

No. 99-007 Jon D. Haveman and Jerry G. Thursby

"The Impact of Tariff and Non-Tariff Barriers to Trade in Agricultural Commodities:

A Disaggregated Approach"

No. 99-008 Huseyin Gulen and Stewart Mayhew

"Stock Index Futures Trading and Volatility in International Equity Markets"

No. 99-009 Stefan Lutz and Alessandro Turrini

"Skills, Labour Costs and Vertically Differentiated Industries: A General Equilibrium Analysis"

No. 99-010 Michael Watts and Alexander Kovzik

"Reforming Undergraduate Economics Instruction in the Former Soviet Union" 